\title{
Oncogenic Effects of HIV-1 Proteins, Mechanisms Behind
}

\author{
Maria Isaguliants ${ }^{1,2,3,4, * \mathbb{D}}$, Ekaterina Bayurova ${ }^{1,2} \mathbb{D}$, Darya Avdoshina ${ }^{1,2}$, Alla Kondrashova ${ }^{2}$, Francesca Chiodi ${ }^{3}$ \\ and Joel M. Palefsky 5
}

\section{check for}

updates

Citation: Isaguliants, M.; Bayurova, E.; Avdoshina, D.; Kondrashova, A.; Chiodi, F.; Palefsky, J.M. Oncogenic Effects of HIV-1 Proteins,

Mechanisms Behind. Cancers 2021, 13, 305. https://doi.org/10.3390/ cancers13020305

Received: 1 December 2020

Accepted: 4 January 2021

Published: 15 January 2021

Publisher's Note: MDPI stays neutral with regard to jurisdictional claims in published maps and institutional affiliations.

Copyright: (C) 2021 by the authors Licensee MDPI, Basel, Switzerland. This article is an open access article distributed under the terms and conditions of the Creative Commons Attribution (CC BY) license (https:/ / creativecommons.org/licenses/by/ $4.0 /)$.
1 Gamaleya Research Center for Epidemiology and Microbiology, 123098 Moscow, Russia; bayurova_eo@chumakovs.su (E.B.); avdoshina_dv@chumakovs.su (D.A.)

2 M.P. Chumakov Federal Scientific Center for Research and Development of Immune-and-Biological Products of Russian Academy of Sciences, 108819 Moscow, Russia; kondrashova_as@chumakovs.su

3 Department of Microbiology, Tumor and Cell Biology, Karolinska Institutet, 17177 Stockholm, Sweden; francesca.chiodi@ki.se

4 Department of Research, Riga Stradins University, LV-1007 Riga, Latvia

5 Department of Medicine, University of California, San Francisco, CA 94117, USA; joel.palefsky@ucsf.edu

* Correspondence: maria.issagouliantis@ki.se or maria.issagouliantis@rsu.lv

Simple Summary: People living with human immunodeficiency virus type 1 (HIV-1) (PLWH) are at increased risk of developing cancer despite successful antiretroviral therapy (ART). Here, authors suggest novel mechanism behind this phenomenon. HIV proteins, namely envelope protein gp120, accessory protein negative factor Nef, matrix protein $\mathrm{p} 17$, transactivator of transcription Tat and reverse transcriptase RT, are known to be oncogenic per se, to induce oxidative stress and to be released from the infected or expressing cells. These properties are proposed to underlie their capacity to affect bystander epithelial cells causing their malignant transformation, and to enhance tumorigenic potential of already transformed/cancer cells. HIV proteins can act alone or in collaboration with other known oncoproteins, specifically originating from the oncogenic human viruses such as human hepatitis B and C viruses, and human papilloma viruses of high carcinogenic risk, which cause the bulk of malignancies in people living with HIV-1 on ART.

Abstract: People living with human immunodeficiency virus (HIV-1) are at increased risk of developing cancer, such as Kaposi sarcoma (KS), non-Hodgkin lymphoma (NHL), cervical cancer, and other cancers associated with chronic viral infections. Traditionally, this is linked to HIV-1-induced immune suppression with depletion of CD4+ T-helper cells, exhaustion of lymphopoiesis and lymphocyte dysfunction. However, the long-term successful implementation of antiretroviral therapy (ART) with an early start did not preclude the oncological complications, implying that HIV-1 and its antigens are directly involved in carcinogenesis and may exert their effects on the background of restored immune system even when present at extremely low levels. Experimental data indicate that HIV-1 virions and single viral antigens can enter a wide variety of cells, including epithelial. This review is focused on the effects of five viral proteins: envelope protein gp120, accessory protein negative factor Nef, matrix protein p17, transactivator of transcription Tat and reverse transcriptase RT. Gp120, Nef, p17, Tat, and RT cause oxidative stress, can be released from HIV-1-infected cells and are oncogenic. All five are in a position to affect "innocent" bystander cells, specifically, to cause the propagation of (pre)existing malignant and malignant transformation of normal epithelial cells, giving grounds to the direct carcinogenic effects of HIV-1.

Keywords: human immunodeficiency virus type 1; epithelial cells; carcinogenicity; oxidative stress; reactive oxygen species; gp120; Tat; Nef; matrix protein p17; reverse transcriptase

\section{Introduction}

Immune suppression and related dysfunctions result in a high prevalence in people living with human immunodeficiency virus (PLWH) of HIV-1/AIDS-associated disorders, 
including so called AIDS-defining cancers (ADC)—Kaposi sarcoma (KS), non-Hodgkin lymphoma (NHL) and cervical cancer. In the era of antiretroviral therapy (ART), their rates have sharply declined: KS by $60-70 \%$ and NHL, by $30-50 \%$ compared to the pre-ART era. Still, the incidence of KS in PLWH remains elevated 800-fold, of NHL 10-fold and of ADC 4 -fold, compared to their rates in the general population. There is also a significant increase in the number of yearly diagnosed cases of non-AIDS-defining cancers [1].

The incidence of these malignancies among PLWH remains elevated compared to that in uninfected population despite successful ART. Traditionally, this is linked to HIVinduced immune suppression with depletion of CD4+ T-helper cells, and exhaustion of lymphopoiesis, however, the immune suppression is much more complex than HIV-1 induced loss of CD4+ T cells. HIV-1 causes dysregulation of the innate immune system, persistent immune activation, dysfunction of the inflammatory response and immune system aging (senescence) early in HIV-1 infection. Successful ART ameliorates, but does not completely correct the major immune dysfunctions [2-6], substantial immunological impairment pertains even on the background of the successful ART $[7,8]$ (for the latest review, see [9]). Hyper-immunoactivation and inflammation persisting in PLWH is recognized as a major cause of HIV-1 associated malignances. This abnormal immunoactivation emerges as the cumulative effect of thymic dysfunction, ART toxicity, persistent antigen stimulation caused by co-infections, microbial translocation, residual viremia and dysbiosis [10], aggravated by incomplete recovery of CD4+ T cell functions and intrinsic $\mathrm{B}$ and $\mathrm{T}$ cell defects on the background of persistent aberrant activation of monocytes, natural killer cells (NK) and innate lymphoid cells [7,11,12].The immune deficiency and dysfunction of the immune system may not be the only cause [13]. Under successful ART, HIV-1 should become latent, however, a study of HIV-1 integration sites in latently infected cell lines evidenced an ongoing viral replication [14], demonstrating that ART cannot fully suppress the process. Massive data have accumulated on the crucial role in high incidence of malignancies among PLWH of the residual virus production and circulating viral proteins. This review concentrates on their role in the high prevalence of cancers among individuals living with HIV-1.

\section{Prevalence of Non-AIDS Defining Cancers Increases Despite Successful Antiretroviral Therapy}

The category of non-AIDS-defining cancers (NADC) includes liver cancer related to infections with hepatitis $\mathrm{B}$ and $\mathrm{C}$ viruses (HBV and $\mathrm{HCV}$ ), brain cancer, and cancers associated with infection with human papillomaviruses of high oncogenic risk (HR HPVs), specifically, the anal cancer.

\subsection{Liver Cancer}

Hepatocellular carcinoma (HCC) is the third-largest cause of cancer-related mortality on a global scale. It constitutes nearly the majority of liver cancer cases, followed by intrahepatic cholangiocellular carcinomas [15]. HCC is a recognized complication of liver cirrhosis, developing stepwise from regenerative to low-grade, then high-grade dysplastic nodules, although in some cases it may also develop de novo [15]. The burden of HCC is expected to increase worldwide in the next few decades, due to the population growth and aging expected in coming years [16]. Treated HIV-1 infection is associated with decreased survival in HCC, independent of stage, anticancer treatment, and geographical origins of the patients [16]. HIV-1 is not sufficient to cause liver cancer on its own, but may promote development of liver cancer by multiple mechanisms not yet fully understood [17]. Although the role of immune suppression in HCV-related HCC is not clear [17], mechanistic evidence suggests an accelerated progression of chronic liver disease to fibrosis and ultimately malignancy mediated by HIV-1-mediated impairment of antiviral CD4+ and CD8+ T-cell responses [18-20].

HIV-1 infection is characterized by increased microbial translocation resulting in elevated levels of circulating lipopolysaccharides (LPS) in the portal and systemic circulations [21]. LPS are well-known inducers of the innate immune activation. Increased levels 
of LPS and/or soluble CD14 (sCD14; reflects LPS-induced monocyte activation) in PLWH on ART correlate with impaired recovery of CD4+ T cells. They also tightly correlated with multiple markers of immune activation, specifically, high levels of type I interferons and activated CD8+ T cells. In HIV-1 infection, these two parameters strongly predict disease progression [21]. In the liver, LPS activate hepatic stellate (HSC) and Kupffer cells (KFC), resulting in the generation of superoxide and release of proinflammatory and profibrogenic cytokines such as TNF- $\alpha$, IL-1, IL-6, and IL-12 that induce liver damage and accelerated liver fibrosis [22]. Activation of Kupffer cells by LPS involves signaling through TLR-4, shown to govern the transition from chronic hepatic inflammation to hepatocellular carcinoma [23]. Another product released from bacterial cell walls, $(1 \rightarrow 3)-\beta$-D-Glucan $(\beta D G)$, emerges as an additional significant source of monocyte and NK cell activation, further contributing to immune dysfunction and inflammation [24].

Growing evidence accumulates of HIV-1 grossly affecting the liver. HIV-1-monoinfected patients demonstrate markers of liver fibrinogenesis/liver injury (by transient liver elastography) correlated with high plasma levels of HIV-1 RNA [25]. HIV-1 RNA has been detected in primary human hepatocytes both ex vivo and in vitro [26,27]. Also many hepatocyte cell lines are permissive to a low level HIV-1 infection although the nature of receptor(s) for HIV-1 on liver cells is unclear [28]. HIV-1 can also directly infect Kupffer cells; infectious replication-competent HIV-1 has been isolated from KFC obtained from liver at autopsy from three HIV-1-infected individuals who died while on ART [29]. Another target of HIV-1 are hepatic stellate cells (HSC), the primary cells involved in liver fibrogenesis, affected through both direct HIV-1 infection and HIV-1 exposure [30]. Interactions of HIV-1, specifically its envelope protein gp120, with chemokine receptors CCR5 and CXCR4 induce cell signaling in HSCs and immune cells within the liver promoting inflammatory responses [31,32]. Direct HIV-1 infection of KFC results in the amplification of proinflammatory responses to LPS [33], enhanced fibrosis and cirrhosis, and exhaustion of virus-specific T-cells. HIV-1-infected HSCs produce collagen I and release monocyte chemoattractant protein-1 (MCP-1) [34]. Exposure of HSCs to HIV-1 results in the production of reactive oxygen species (ROS), and expression of collagen and tissue inhibitor of matrix metalloproteinases-1 (TIMP1) [35]. These events, together with abnormalities in the gut microbial communities, significantly contribute to the high rates of liver cancer in PLWH [36] (Figure 1).

Even more important driving force of hepatocellular carcinogenesis in PLWH is coinfection with HBV and HCV [37]. In HIV-1/HBV and HIV-1/HCV co-infected patients, HIV-1 infection decreases the rate of spontaneous viral clearance from the liver, accelerates fibrogenesis and increases the rates of liver-related morbidity and mortality, including the development of HCC $[30,38]$. In HIV-1/HCV co-infected individuals HCC occurs at a younger age and after a shorter period of HCV infection than in HIV-1 negative individuals [39], with the risk to develop HCC increasing each year by 11\% [19]. Important risk factors for the progression to liver cancer are high HBV and HCV viral loads $[18,19,40]$. They are associated with (over)expression of viral oncoproteins known to induce oxidative stress and chromosomal instability/genomic damage, promote chronic inflammation with liver damage resulting in the malignant transformation of liver cells [41,42] (Figure 1).

\subsection{Brain Cancer}

PLWH are highly predisposed to developing brain cancer, including primary central nervous system lymphomas (PCNSL) and glioblastomas (GBM) $[43,44]$. In pre-ART era, brain tumors were registered in $10 \%$ of PLWH [43]. Prevalence of PCNSL in AIDS patients was 3600-fold greater than in the general population, reaching $12 \%$ in AIDS patients [44]. ART has dramatically reduced these rates, possibly due to the effect of protease inhibitors [45]. Still, the prevalence of brain tumors in PLWH appears to be higher than in general population: in USA; recorded prevalence of PCNSL in HIV-1 infected is $8.4 \%$ compared to $<3.3 \%$ in the general US population $[45,46]$ Also GBM occurs in PLWH (in various stages of HIV-1 infection) at a younger age and at a frequency 5.4- to 45-fold higher than in 
the general population [47]. Furthermore, the median survival rate in patients with GBM for PLWH is shorter than for HIV-1-negative patients receiving same treatment (an average of 8 compared to 14 months, respectively) [48].

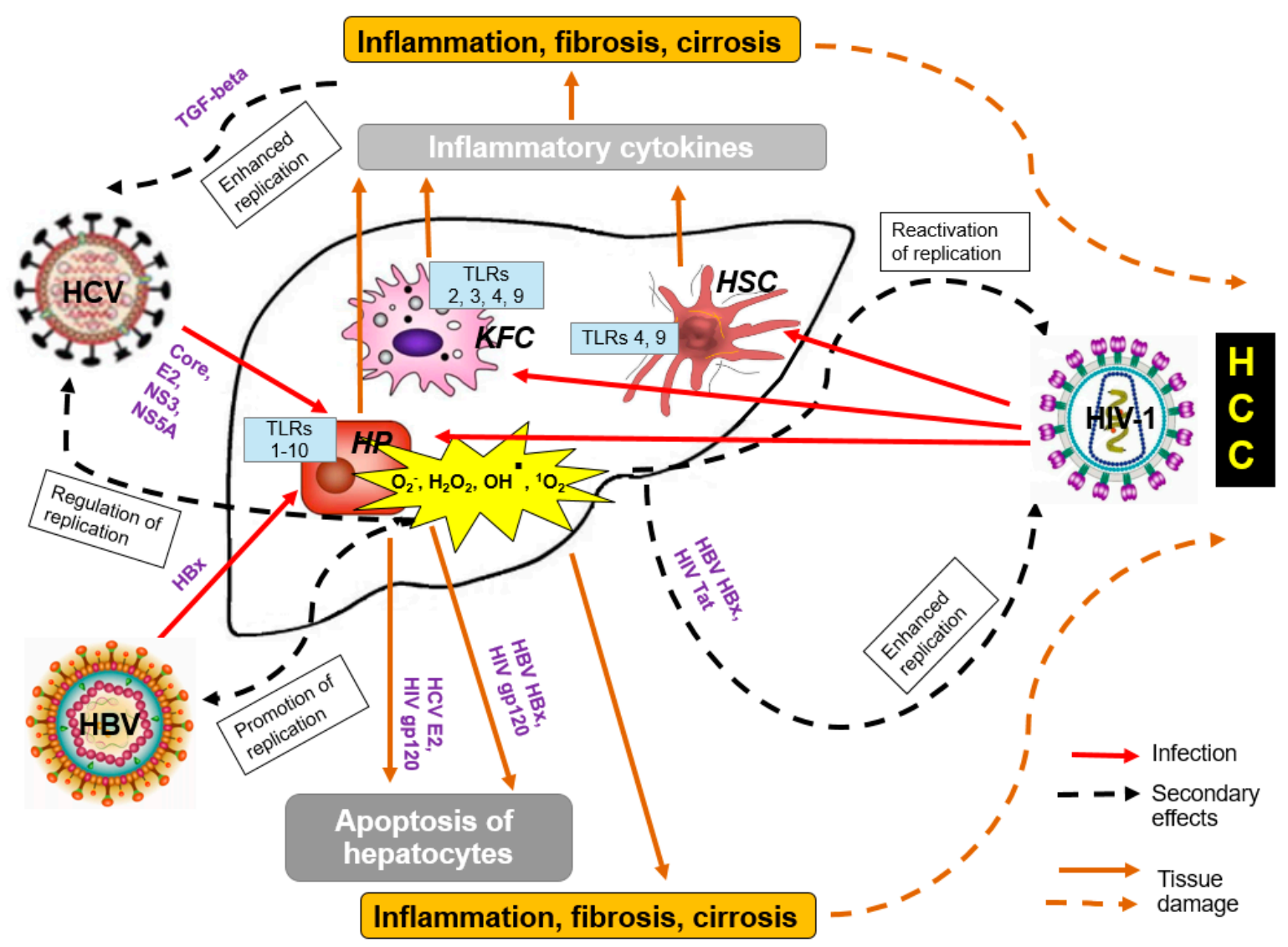

Figure 1. The effect of HIV-1 on cells of the liver. Infection with HIV-1 and even exposition of hepatocytes (HP), hepatic stellate cells (HSC), Kupffer cells (KFC) to HIV-1 leads to production of reactive oxygen species (ROS) and induction of proinflammatory microenvironment, which in turn, promote/enhance replication of HBV, HCV, as well as HIV-1 itself, resulting in enhanced fibrosis, cirrhosis and development of hepatocellular carcinoma (HCC). Infections are depicted in red, secondary effects in dashed black, and events leading to tissue damage in ochre-colored lines.

The nature of the brain tumor-HIV-1 relationship is not fully understood. The majority of these tumors are central nervous system lymphomas but gliomas may develop as well. GBM tumors appear approximately three years after HIV-1 infection [43]. The stimulatory effect of HIV-1 infection on the development of GBM has been associated with reduced immune surveillance. However, survival of PLWH after GBM diagnosis is not associated with CD4+ cell counts [47]. The absence of a correlation between GBM development \& progression with immune incompetence $[47,49-51]$ indicates that aggressive tumor behavior is not a direct consequence of the immune deficiency and suggests direct involvement of HIV-1 in the initiation and progression of brain cancers. Importantly, HIV-1 infection in the brain is not limited to microglia/macrophages, but also affects astrocytes, which can then serve as a potential reservoir for further productive infection, viral persistence, and latency $[52,53]$.

\subsection{Squamous Cell Carcinomas}

PLWH suffer from squamous carcinomas at numerous sites including the lung, anogenital region, oral cavity, epiglottis and cervix. Many of these malignancies are associated with infection by human papillomaviruses of high carcinogenic risk (HR HPVs). Similar to the rates of liver and brain cancer, the rates of HR HPV-associated cancers in PLWH are steadily growing despite successful ART [54-56]. CD4+ levels and resulting immune 
suppression play a prominent role in controlling HPV replication and development of early disease, particularly, the development of pre-cancerous intraepithelial neoplasia: in PLWH, the probabilities of HPV acquisition and development of intraepithelial neoplasia increase in proportion to the loss of CD4 T cells [57]. However, progression to high-grade lesions and further to cancer is not predetermined by $\mathrm{CD} 4+$ depletion, i.e., is not a straightforward outcome of HIV-1-induced immune suppression [58,59], but rather an outcome of the accumulated changes in the host cell genome and transcriptome involving tumor suppressor genes, apoptosis-related genes, DNA damage-repair genes, and cell cycle regulatory genes $[58,60,61]$.

Question arises how could this rely to the epithelial cells which are considered to be non-susceptible to HIV-1 infection and non-permissive to HIV-1 replication? HIV-1 infects a variety of immune cells, such as CD4+ T lymphocytes and monocytes/macrophages. However, several studies show that it may also infect or rather "trespass" other cell types, in which HIV-1 virions and individual HIV-1 proteins were repeatedly detected. In primate models, application of HIV-1 to the surfaces of oropharyngeal [62], anal/rectal [63], cervicovaginal and foreskin/penile [62,64-66] epithelia was shown to lead to subsequent systemic infection of HIV-1-susceptible immune cells, indicating that HIV-1 travels through these tissues to reach its targets. Indeed, application of HIV-1 to human foreskin, vaginal and cervical tissue explants ex vivo leads to the transmission of HIV-1 across these epithelia [64,66-71].

These findings are not restricted to the epithelial cells of the reproductive tract. HIV1 antigens and RNA were detected in gastric epithelial cells in the biopsy and autopsy samples of HIV-1-infected patients; furthermore, TEM analysis visualized HIV-1 particles in the cytoplasm of gastric epithelial cells [72]. Interestingly, HIV-1 load in blood positively correlated with the number of HIV-1-infected gastric epithelial cells. The latter increased with progression of chronic infection, being significantly higher at the AIDS compared to the asymptomatic stage. HIV-1 infection of gastric epithelial cells associated with a severe inflammatory response in the gastric mucosa manifested by infiltration and aberrant activation of the immune cells [72].

Another example is presented by human mammary epithelial cells (MEC). MEC express HIV-1 receptors CD4, CCR5, CXCR4, and galactosyl ceramide (GalCer). Although the evidence for direct MEC infection by HIV-1 was missing, HIV-1 virions were found in the endosomal compartments of these cells. Furthermore, activated CD4+ T cells co-cultured with HIV-1-exposed MEC were productively infected with HIV-1 [73]. This confirmed that mammary epithelial cells can endocytose HIV-1 and facilitate its transfer to CD4+ T lymphocytes [73]. At the other end, a contact-dependent HIV-1 transfer was shown from HIV-1-infected macrophages to both primary and immortalized renal tubule epithelial cells (RTE). Live imaging of HIV-1 infected RTE cells revealed four different fates: latency, hypertrophy, cell death, and proliferation [74]. HIV-1 can also enter airway epithelial cells and alter their function by increasing the expression of inflammatory mediators [75]. This data unequivocally demonstrate that HIV-1 could be internalized and/or sequestered by human epithelial cells of different origins.

\section{Mechanisms Underlying HIV-1 Pathogenicity in Epithelial Cells}

In CD4+ cells HIV-1 was reported to preferably integrate into cancer-associated genes or cell cycle regulation genes dysregulation of which can lead to cancer formation as was described for other retroviruses [76-78]. Replication of HIV-1 in epithelial cells has not been shown except for the early findings of human uterine epithelial cells productively infected by HIV-1 with reverse transcription of viral RNA, transcription of viral DNA, and secretion of infectious virus [79]. Of note, co-cultivation of human CD4+ T cell lines with HIV-1-infected uterine epithelial cells (and also by virions released by these cells) led to HIV-1 infection of the CD4+ T cells [79]. Bulk of data accumulated so far evidence sequestration of HIV-1 by human epithelial cells of different origins without evidence of productive replication or integration. However, a "real" infection can take place as well. 
HIV-1 was shown to hijack other viral Envs to directly enter CD4-negative cells through pseudotyping [80-82]. Lately, Tang Y. et al. have shown that HIV-1 infected T cells can fuse to and transfer the virus to placental trophoblasts, if the later express on their surfaces the envelope glycoprotein of human endogenous retrovirus family W1, syncytin [83]. This leads to the formation of an HIV-1 reservoir in the epithelial cells [83]. Syncytin-1 derives from a family of endogenous retroviruses and originates from HERVW1 infection of human germ cells [84]. Expression of syncytin could be a common feature of an epithelial cell which make them susceptible to HIV-1 via a "non-canonical" route of HIV-1 infection. These are not necessarily the epithelial cells of placenta. According to the recent preliminary report published in bioRxiv, HIV-1 can infect human bronchial epithelial cells; after exposition to HIV-1 they were shown to express p24 and contain latent HIV-1 provirus [85]. These findings along with the data by Asin SN et al. [79] indicate that in certain cases epithelial cells can be infected with HIV-1, possibly as a one-round abortive infection with reverse transcription of RNA and integration of the proviral DNA governed by respective enzymes constituting HIV-1 virion. Such integrated proviral HIV-1 DNA would not only serve as an HIV-1 reservoir, but would also give progeny to the genetically modified cells (with proviral DNA inserts) susceptible to malignant transformation. The observation by Hughes K et al. of a proliferation of HIV-1 infected epithelial cells consistent with clonal expansion of individual cells ideally fits this scenario [74].

HIV-1 antigens may also affect epithelial cells without infecting them. Epithelial cells may respond to the defective virions incapable of productive infection or freely circulating HIV-1 antigens shed by the infectious or defective virions. Addition of HIV-1/HIV-1 antigens to the epithelial cells generates an inflammatory microenvironment or rather microenvironmental immune abnormalities [86-88] (as those associated with HR HPV infection). Microenvironment of B-cell lymphomas in PLWH is characterized by expression of CD3, CD4, CD8, CD56, CD68, CD163, FOXP3, TIA1, granzyme B, perforin, CD57, CD34 and PD-1 [89], and enrichment with soluble factors, including cytokines IL-1, IL-2, IL6, IL10, and chemokines of the CCL and CXCL families $[89,90]$. Such microenvironment was also found in the intraepithelial cancerous lesions of PLWH [91]. Studies on the mucosaassociated lymphoid tissue system (MALT) in PLWH have shown abnormal immune responses in the mucosal milieu, including upregulation of expression of multiple regulatory cytokines such as IL-8, IL-23, TNF- $\alpha$, IL-17A, and IFN- $\gamma$ (TNF- $\alpha /$ IL-17A/IFN- $\gamma$ triad), the depletion of Langerhans cells and CD3+ lymphocytes, increases in Foxp3+ T-regulatory cells, and in local lymphocyte infiltrates composed by CD8+ T cells, associated with the development of high-grade squamous intraepithelial lesions (HSILs) [91-94].

Furthermore, presence in the epithelial cells of HIV-1/HIV-1 proteins modulates their capacity to express E-cadherin, a marker of epithelial to mesenchymal transition (EMT) $[69,75,95]$. HIV-1 interaction with the surface of mucosal epithelial cells was also shown to activate the transforming growth factor-beta (TGF- $\beta$ ) and mitogen-activated protein kinase signaling pathways [96]. When activated, these pathways may lead to the disruption of epithelial junctions and EMT [97]. Indeed, EMT was induced by exposure of oral keratinocytes from HIV-1-negative individuals to HIV-1 virions as well as Tat and gp120 proteins [98]. Within premalignant cells or in the environment of the malignant cells, HIV-1 driven EMT would promote motile/migratory cells and accelerate the neoplastic process.

Altogether these observations imply direct carcinogenic effect(s) of HIV-1 virions and/or antigens. This concept, proposed in 2002 by B Clarke \& R Chetty [58] and four years later by Palefsky JM [59], is now supported by considerable experimental proof. It brings up several issues of importance for epithelial cells: (i) could malignant transformation be promoted by cooperation of HIV-1 with other oncogenic viruses; (ii) which HIV-1 antigens are implicated; and finally (iii) what are the underlying molecular mechanisms? 


\section{Potentiation of Carcinogenesis by Interactions of HIV-1 with Other Oncogenic Viruses}

Oncogenic transformation associated with virus infection was for a long time considered to result from a mono-infection (infection with a single virus). However, it is now established that in many cases induction of cancer depends on the simultaneous presence and interactions of multiple viral agents in diverse combinations. Viruses co-infecting human tissues may have synergistic or regulatory effects on carcinogenesis, targeting existing neoplastic cells as well as their microenvironment including reactive T-cells, B cells and macrophages, and non-immune cells such as endothelial cells. HIV-1, in particular, potentiates the effects of $\mathrm{EBV}, \mathrm{KSHV}, \mathrm{HCV}$, and $\mathrm{HPV}$ oncogenes, promoting carcinogenesis in individuals co-infected with HIV-1 and EBV, KSHV, HCV, HBV, and HPV. Here, we will focus on molecular interactions of HIV-1 with HBV, HCV, and HPVs.

Progression to liver cancer/HCC in HIV-1/HBV and HIV-1/HCV co-infected patients is promoted by direct and indirect interactions between these viruses and their antigens within the cells harboring HIV-1 due to infection or sequestration of the virion (viral proteins). HIV-1 infection of hepatic cell lines increases the expression of HBV antigens [27]. HIV-1 gp120 causes intracellular accumulation of HBV DNA as well as HBsAg causing hepatotoxicity [99]. Direct interaction of HIV-1 and HBV in liver cells has been demonstrated, with the HBV X protein interacting with HIV-1 Tat to facilitate HIV-1 replication [99]. Upon co-cultivation of HIV-1 infected Jurkat cells with hepatocytes, up-to $16 \%$ of the latter acquire Nef. Sequestered Nef alters the size and numbers of lipid droplets (LD), inducing 1.5 to 2.5 fold up-regulation of replication of HCV subgenomic replicon, a remarkable finding in relation to the initially indolent viral replication. Nef also dramatically enhances the ethanol-mediated up-regulation of HCV replication accelerating progression to HCC [100]. HIV-1 gp 120 also causes TGF- $\beta$ mediated up-regulation of HCV replication [86]. Taken together, these data indicate that HIV-1 and single HIV-1 proteins are critical elements in accelerating progression of liver pathogenesis by enhancing HBV and HCV replication and coordinating production of key intra- and extra-cellular molecules that orchestrate liver decay [100].

One of the mechanisms of HIV-1 potentiation of liver cancer is the induction of oxidative stress. HCV, HIV-1 (and antiretroviral therapy) act together to activate production of ROS in HSCs and hepatocytes. ROS promote phosphorylation of the major mitogenactivated protein kinases active in human cells, p38 kinase, c-JUN N-terminal kinase (JNK) and extracellular signal-regulated kinase (ERK) that control cell growth, differentiation and apoptosis. In their turn, the phosphorylated p38 MAPK, JNK, and p42/44 ERK phosphorylate nuclear factor kappa-light-chain-enhancer of activated B cells (NF- $\mathrm{KB}$ ) protein complex, mastering transcriptional regulation of inflammation and cell death [31]. Following these events, phosphorylated NF- $\mathrm{KB}$ translocates to the nucleus, and where it normally modulates the production of both pro- and antifibrogenic/antiapoptotic genes, ensuring that liver cells are protected from apoptosis, but are capable to build the required inflammatory and immune responses [101]. In the presence of LPS, NF- $\mathrm{kB}$ can upregulate the expression of profibrogenic genes, such as procollagen $\alpha 1$, transforming growth factor $\beta 1$ (TGF- $\beta 1$ ) and tissue inhibitor of MMPs (TIMP-1) [31,101]. This process is accelerated by HIV-1/HIV-1 proteins: exposure of hepatocytes to HIV-1/HIV-1 proteins results in the elevated production of ROS and increased expression of collagen and TIMP1, further amplified by HCV infection, and even exposure to infectious HCV [35]. Taken together, these data indicate that HIV-1-mediated potentiation of hepatocellular carcinogenesis reflects a concerted action of HIV-1, HBV and HCV as viruses and/or individual viral proteins (Figure 1). Based on compelling data, McGivern \& Lemon even suggested that the path to hepatocellular carcinoma in chronic hepatitis $C$ shares important features with the carcinogenesis induced by HPV [102]. 
The increased risk of PLWH developing HPV-associated cancer can also, at least in part, be due to the interactions between HIV-1 and HPV. In general, epithelial cells of PLWH show loss of E-cadherin, and upregulation of vimentin and TGF-b1 expression with spindle-like morphology indicating induction of TGF-b1-dependent EMT, critical for malignant transformation. As noted above, EMT is induced not only due to HIV-1 infection, but also through exposition of epithelial cells to HIV-1 proteins $[69,75,95,97]$. EMTinduced keratinocytes can then be infected with pseudoviral HPV16 particles (HPV-16 PsVs) and whole HPV16 virus, with infected cells expressing viral oncogenes E6/E7, whereas unexposed keratinocytes could not be infected with either PsVs, or infectious HPV16. Furthermore, "HIV-1-induced" EMT keratinocytes could be transformed with HPV16 DNA, transformed cells showing active proliferation and migration [103]. This confirms that prolonged exposure to and interaction of HIV-1 with oral and anal epithelial cells induces EMT. EMT-induced loss of cell adhesion and increased proliferation and mobility of epithelial cells play a critical role in HPV infection and HPV-associated transformation. HIV-1-induced EMT in the orogenital mucosa may promote progression of pre-cancerous HPV-associated neoplasia to cancer in HIV-1-infected individuals [103].

"Molecular" cooperation between HIV-1 and HPV has not been sufficiently well characterized, but there are relevant examples in this field. Tat protein was shown to transactivate the HPV long control region and increase expression of oncoprotein E7 of HPV18 in HeLa cells [104,105]. Tat can upregulate the expression of E6 and E7 oncoproteins of HPV type 16 in HPV 16-infected human oral keratinocytes, notably enhancing the in vitro proliferative capacity of these cells [106,107], and increase the transcription of E2 modulating HPV replication [108]. The direct angiogenic effects of Tat [109] or its capacity to up-regulate the expression of E6 and E7 of HR-HPVs [110] allows Tat to favor the angiogenic switch in high-grade CIN. We have shown that gp120 and reverse transcriptases (RT) derived from various HIV-1 strains, can increase the expression of HPV 16 E6 in a cervical cancer cell line containing full-length HPV 16 genome Ca Ski (Figure 2), while HIV-1 p24 exerts no effect. In similar conditions, gp120 increases the expression of HPV16 E6 also in HPV16 immortalized anal epithelial AKC2 cells [104,106,111,112]. Furthermore, Tugizov et al. have shown that in the HPV-immortalized anal and cervical epithelial cells Tat and gp120 proteins induce the EMT phenotype, leading to increased migration of cells via collagen membranes [103]. The data on the interaction(s) between HPV and other HIV-1 proteins is missing.

Overall, these findings indicate that the increased incidence of AIDS-defining and nonAIDS defining forms of cancer in PLWH may reflect the direct or indirect, often concerted, carcinogenic effect(s) of HIV-1 and/or individual HIV-1 proteins on diverse infected as well as uninfected bystander cells. Furthermore, some HIV-1 proteins appear to be directly involved in cell transformation and propagation of malignant cells. 


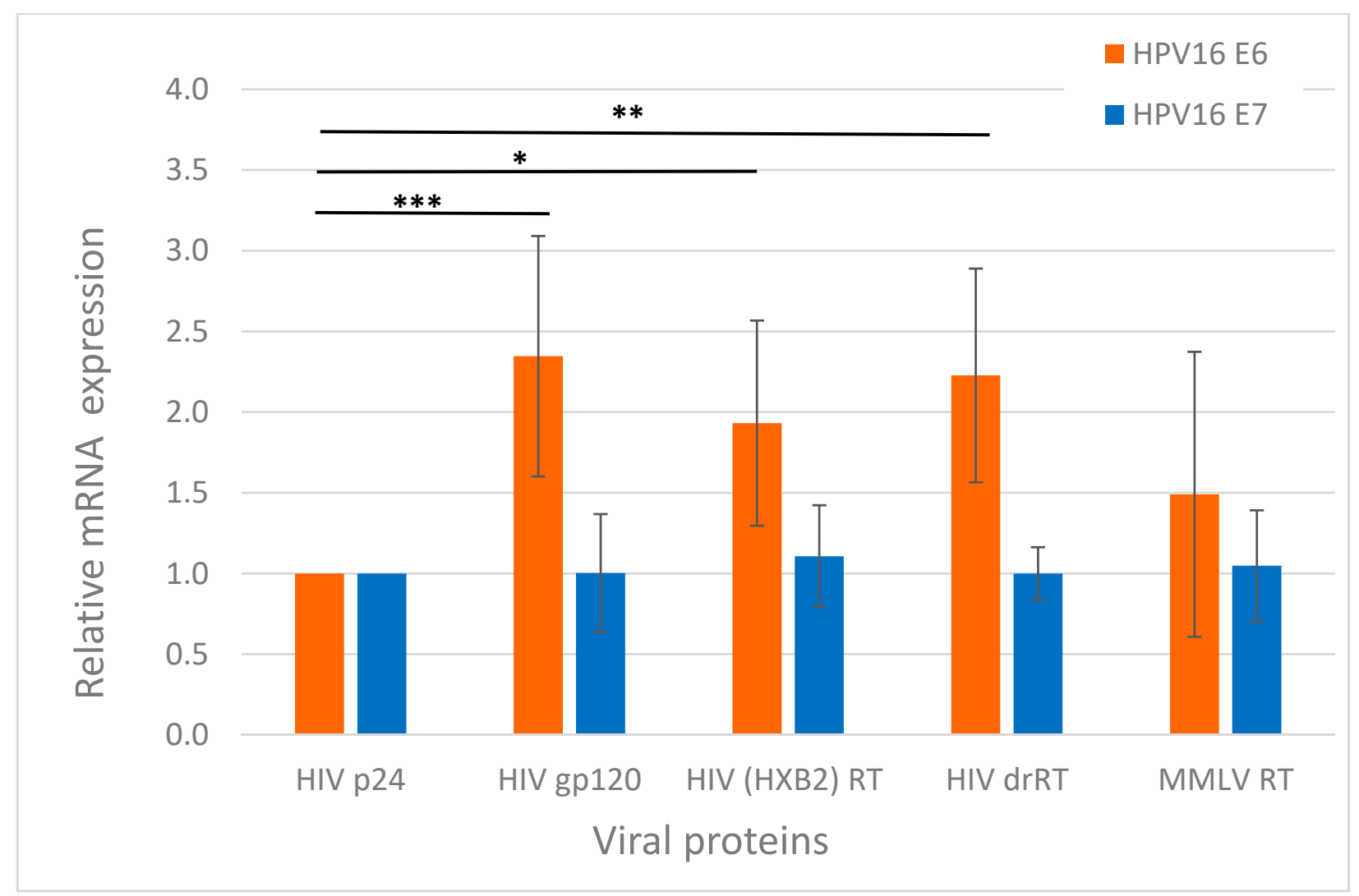

Figure 2. Transcription of oncoproteins E6 and E7 of HPV 16 in Ca Ski cells treated with HIV-1 proteins. Ca Ski cells harboring 600 full genomic copies of HPV 16 (ATCC CRL-1550) were cultured in RPMI-1640 medium (PanEco, Moscow, Russia) supplemented with $10 \%$ FBS and $100 \mathrm{mg} / \mathrm{mL}$ penicillin/streptomycin mix at $37{ }^{\circ} \mathrm{C}$ in an $5 \% \mathrm{CO}_{2}$ and split every 4 days. A panel of recombinant HIV-1 proteins: gp120 [113]; p24 (NIBSC ARP 694.1); RT of HIV-1-1 clade B HXB2 strain [114], drug resistant (dr) RT of HIV-1-1 clade B isolated from patient with multiple drug resistance mutation (RT1.14; [114]) and RT of Moloney murine leukemia virus (MMTV) (CRIE, Moscow, Russia) were added to the culture medium, typically in concentration of $1 \mathrm{ng} / \mathrm{mL}$, and incubated for $48 \mathrm{~h}$, according to the methodology described previously by Lein K. et al. [115] Total RNA was extracted and reverse transcribed as described by Jansons et al. 2020 [116]. Gene-specific PCRs were performed on Rotor-Gene 6000 (Qiagen, Darmstadt, Germany) with SYBR Green kit (Evrogen, Moscow, Russia) with primers specific to HPV 16 E6 and E7 [117]. Expression of mRNA, assessed by the standard ddCt method, was normalized to expression of 18S RNA (18Srna_rt_f: GTAACCCGTTGAACCCCATT; 18Srna_rt_r: CCATCCAATCGGTAGTAGCG), and presented as fold change compared to cells treated with p24, as was recommended earlier [118]. Values represent mean \pm SD from two independent assays run in duplicates. ${ }^{* *} p<0.001,{ }^{* *} p<0.01,{ }^{*} p<0.05$ by the ordinary two-way ANOVA with Sidak's multiple comparisons test.

\section{HIV-1 Antigens Involved in Cell Transformation and Tumor Propagation 5.1. Transactivator of Transcription (Tat)}

Tat has long since been known to influence cell cycle progression. In HeLa cells, Tat induces a significant increase in the levels of proliferation markers together with the reduction in the expression of cell cycle inhibitors of transcription [119]; it inhibits epithelial differentiation, blocks apoptosis in vitro and accelerates tumor formation in vivo [119]. In addition, Tat significantly increases in vitro migration in the absence of fetal calf serum [119]. These results suggest that HIV-1 may enhance carcinogenesis by promoting cell cycle progression [111]. Furthermore, it has been shown that binding of Tat to Tat-interacting promoter 30 (TIP30) enhanced EMT and metastasis of non-small cells lung cancer cells by regulating the nuclear translocation of Snail [120]. One of the possible mechanisms of Tat induced carcinogenesis is blocking at the mRNA level of the expression of a Rb family member pRb2/130 and cyclin-dependent kinase inhibitors p21 and p17 [111]. The transduc- 
tion domain of Tat specifically attenuates growth of polyamine-deprived tumor cells [121]. Tat is also known to modulate VEGF and targets VEGFRs which increases angiogenesis and supports tumor growth [122]. Furthermore, Tat alters DNA repair in host cells, potentially leading to genomic instability $[123,124]$. Specifically, Tat induces expression of the DNA polymerase beta gene, which codes for a central mediator in the DNA base-excision repair pathway [125]. It also interferes with double-strand break DNA repair, as cellular extracts containing Tat possess a reduced capacity to re-join linearized DNA [126], indicating that Tat, as well as cellular co-factors of Tat, interfere with repair of double-stranded DNA breaks [123].

\subsection{Envelope Glycoprotein gp 120}

Glioma cells were shown to interact with the HIV-1 envelope protein gp120. This interaction promotes proliferation, migration, survival and stimulates glycolysis in glioma cell lines and tumor growth in animal models [127]. Increased glycolysis, also known as the Warburg effect characteristic of malignancy [128], results in increased protein and lipid synthesis, and promotes uncontrolled propagation (both proliferation and invasion) of tumor cells, as it provides them with glycolytic intermediary precursors required for the synthesis of DNA, proteins and lipids [127,129]. As Tat, gp120 induces EMT and cell migration through the TGF-B1 and MAPK signaling pathways $[115,130]$.

\subsection{Accessory Protein Negative Factor (Nef)}

Nef is one of the earliest and most abundantly expressed HIV-1 proteins. Nef has the ability to modulate multiple cellular signaling pathways in both CD4+ lymphocytes and macrophages. Nef inhibits the apoptotic function of p53 due to its ability to decrease p53 protein half-life and, consequently, p53 DNA binding activity and transcriptional activation [131]. Both internalized and ectopic expression of Nef in endothelial cells synergizes with Kaposi's sarcoma (KS) KSHV oncoprotein K1 to facilitate vascular tube formation and cell proliferation, and enhance angiogenesis in the chicken chorioallantoic membrane (CAM) model. In vivo experiments further indicate that Nef can accelerate K1-induced angiogenesis and tumorigenesis in athymic nu/nu mice [132]. On non-small lung cancer A549 cells, Nef promotes cell proliferation, migration, anchor independent growth and reduces the levels of expression of p53, increasing the aggressiveness of cancer cells [133].

\subsection{Reverse Transcriptase (RT)}

We have shown that constitutive expression of HIV-1 RT in murine mammary gland adenocarcinoma 4T1 cells leads to upregulation, in a concentration-dependent manner, of the expression of the transcription factors Twist and Snail tightly involved in EMT [134] In vivo, expression of RT by 4T1 cells results in enhanced tumor growth and potentiates formation of metastasis in distal organs of immunocompetent syngenic mice [134]. Interestingly, this is not a common property of the reverse transcriptases, as constitutive expression of enzymatically active reverse transcriptase domain of telomerase reverse transcriptase, on contrary, suppressed both tumor growth and metastatic activity of 4T1 cells [116].

\subsection{Matrix Protein $p 17$}

Matrix/p17 protein induces expression of chemokines [135], exerts pro-angiogenic [136] and lymphangiogenic [137] activities, and deregulates the biological activity of diverse cells of the immune system [138]. Overall, p17 generates a prolymphangiogenic microenvironment, predisposes the lymph node to lymphoma growth and metastasis [137] and promotes the aggressiveness (propagation) of human triple-negative breast cancer cells [139]. In a HIV-1 transgenic mouse model of lymphoma, only expression of HIV-1 p17, but not of other HIV-1 proteins, induced spontaneous B-cell lymphomas in HIV-1 transgenic mice, with p17 expressed at high levels in the early stages of the disease [140]. Murine lymphoma tissues exhibited enrichment in expression of the recombination-activating genes (Rag1/2) [140]. 
The latter suggests that intracellular signaling induced by p17 leads to genomic instability and promotes the transformation [140].

Thus, several HIV-1 proteins are directly or indirectly oncogenic, stimulating transformation of healthy cells and propagation and aggressiveness of already existing cancer cells. These oncogenic properties are linked to two essential characteristics of these proteins: their capacity to induce oxidative stress with production of reactive oxygen species and their ability to exit HIV-1-infected cells (active or passive transport).

\section{Oncogenic HIV-1 Proteins Induce Oxidative Stress}

Virally-induced cancer evolves over long periods of time in the context of a strongly oxidative microenvironment, on the background of chronic inflammation. Oxidative stress induced by chronic viral infection is one of the factors driving neoplastic transformation, ultimately leading to oncogenic mutations in many cellular signaling cascades that drive cell growth and proliferation [42,141]. Oxidative damage of chromosomal DNA and chronic immune-mediated inflammation are key features of HBV, HCV, HPV, and HIV-1 infections [42,141]. As we have earlier reviewed, numerous lines of evidence show that HIV1 infection triggers pronounced oxidative stress in both laboratory models and the context of in vivo infection by deregulation of oxidative stress pathways with escalation of ROS production and by inducing mitochondrial dysfunction [141]. As a result, PLWH exhibit multiple markers of oxidative stress including DNA damage [134,142]. The enhancement of ROS production is mediated by the envelope protein Gp120, Tat, Nef, RT, and p17 [141-146].

\subsection{Transactivator of Transcription}

Tat induces oxidative stress both directly and indirectly via several independent mechanisms. The first involves the NADPH oxidases [147], and in the second, an enzyme involved in the catabolism of biogenic polyamines, spermine oxidase (SMO) [148], and the third, a mitochondrial dysfunction [149]. A detailed analysis of the levels of ROS in different subcellular compartments of the HIV-1 infected cells revealed a strong increase in the levels of $\mathrm{H}_{2} \mathrm{O}_{2}$ in the endoplasmic reticulum (ER), demonstrating with the help of genetically encoded ratiometric sensor HyPER $[150,151]$. This indicated the involvement in $\mathrm{H}_{2} \mathrm{O}_{2}$ production of NOX4 which primarily resides in ER [152]. The levels of $\mathrm{H}_{2} \mathrm{O}_{2}$ in the cytoplasm and mitochondria were not elevated [151]. The above activities of Tat are thought to underlie the onset of HIV-1-associated dementia [109,150].

\subsection{Envelope Protein Gp120}

Early findings indicated that gp120 increases free radical production from monocytederived macrophages (MDM) detected by spin-trapping methods, and that the spin trap adduct results from a reaction involving nitrogen oxide $\mathrm{NO}$ or its closely related oxidized derivatives [153]. We have earlier summarized a profound role of gp120 in the induction of oxidative stress [141], namely gp120 induces ROS production in cell lines of lymphoid origin, in the endothelial brain cells, astrocytes, neurons and microglia. In astrocytes, it enhances ROS production by several parallel mechanisms: via Fenton-Weiss-Haber reaction, NOX2 and NOX4, and cytochrome P450 2E1 (CYP2E1) [154,155]. The latter is mediated through the upregulation of CYP2E1 expression. In cancer (neuroblastoma) cells, gp120 induces proline oxidase that synthesized pyroline-5-carboxylate with concomitant generation of ROS (reviewed in [141]).

The effect of HIV-1/HIV-1 proteins on the cellular antioxidant defense system is controversial. They can both suppress and enhance antioxidant defense pathways [141]. Gp120 was shown to induce oxidative stress response. It up-regulates functional expression in cultured astrocytes of multidrug resistance protein 1 (Mrp1) which effluxes endogenous substrates glutathione and glutathione disulphide involved in cellular defense against oxidative stress [156]. It also upregulates the expression of nuclear factor erythroid derived 2-related factor 2 (Nrf2), a basic leucine zipper transcription factor which is known to regulate antioxidant defensive mechanisms) in human astrocytes, stimulating expression of 
key antioxidant defensive enzymes hemoxygenase (HO-1) and $\mathrm{NAD}(\mathrm{P}) \mathrm{H}$ dehydrogenase quinone1 (Nqo1) [157]. Pre-treatment of astrocytes with antioxidants or a specific calcium chelator BAPTA-AM, significantly blocks the upregulation of Nrf2, HO-1 and Nqo1 [157].

\subsection{Accessory Protein Negative Factor}

Nef protein has pro-oxidant activity in microglial cells and in neutrophils. It first induces phosphorylation and then translocation of the cytosolic subunit of NADPH oxidase complex p47(phox) into the plasma membrane which in turn induces superoxide anion release from macrophages [158,159]. As a multifunctional HIV-1 protein, Nef also activates the Vav/Rac/p21-activated kinase (PAK) signaling pathway involved in activation of phagocyte NADPH oxidase (thus, Nef indirectly activates NADPH oxidase) [160]. This leads to the dramatic augmentation of the production of ROS [100], and enhancement of cell responses to a variety of stimuli $(\mathrm{Ca}(2+)$ ionophore, formyl peptide, endotoxin) [160]. It also leads to decreased tolerance of the cells to hydrogen peroxide, specifically in astrocytes which normally support neuronal function and protects them against cytotoxic substances including ROS [161]. Rac1-dependent NOX2-mediated reactive oxygen species production was shown to contribute to ongoing HIV-1-related vascular dysfunction [162].

\subsection{Reverse Transcriptase}

We have previously demonstrated that expression of RT by human cells induces production of ROS [163]. Later studies demonstrated that this is a property of different RT variants, including drug resistant variants, and variants retargeted for lysosomal processing and secretion [114,163]. Expression of all RT variants led to an increase in the levels of expression of Phase II detoxifying enzymes HO-1 and Nqo-1. Artificial secretion of RT resulted in a decrease of RT capacity to induce oxidative stress with a decrease in the production of ROS compared to the parental enzyme [114].

\subsection{Matrix Protein $p 17$}

There is no direct evidence of p17-induced oxidative stress. However, p17 possesses specific structural motifs defined as "coiled coil" sequences, and has a high propensity to form multimers, mis-fold and aggregate, forming amyloidogenic assemblies [164,165]. This is typical to amyloidogenic proteins actively involved in the pathogenesis of many human diseases, such as Alzheimer's disease and Parkinson' disease. Amyloidogenic assemblies are toxic, specifically to neural cells. Experiments in the invertebrate nematode Caenorhabditis elegans as a "biosensor" demonstrated that p17 significantly inhibits its pharyngeal contractions as do the amyloidogenic proteins [166]. Intrahippocampally injected into mice, p17 induced neurocognitive disorders, comparable in strenght to the effects of other known amyloidogenic proteins [166]. Interestingly, amyloidogenic proteins (typically amyloid-beta peptide $A \beta$ ) bound to redox active metal ions, such as copper, catalyse the production of ROS, in particular the most reactive one, hydroxyl radical. This effect may underlie the observed oxidative damage exerted by A $\beta$ peptide on itself and on the surrounding molecules (proteins, lipids, DNA) [167]. One can hypothesize that matrix protein $\mathrm{p} 17$ with its amyloidogenic assemblies may trigger the production of ROS through a similar mechanism.

Thus, HIV-1 proteins with known oncogenic/mitogenic potential, Tat, gp120, Nef, $\mathrm{RT}$, and potentially $\mathrm{p} 17$, have a potential to directly or indirectly induce oxidative stress, which could be one of the mechanisms by which they induce and potentiate carcinogenesis (Figure 3). Interestingly, HIV-1 proteins with an oncogenic potential involved in the induction of oxidative stress, such as Tat, gp120, Nef, RT, and possibly p17, can be found outside of the cells in which they are expressed. 


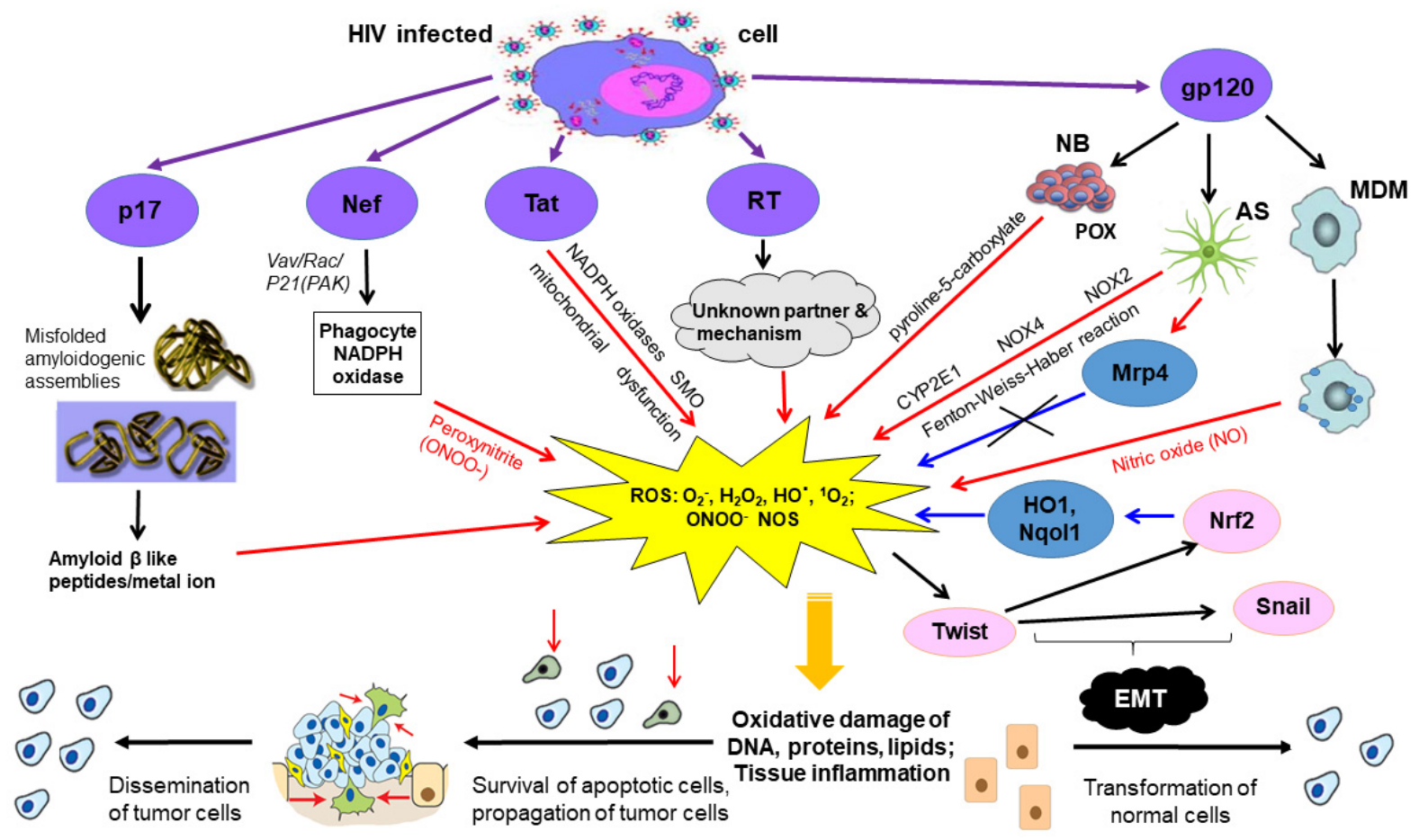

Figure 3. Suggestive mechanism of direct carcinogenic effects of HIV-1 proteins. HIV-1 infected cells express and release gp120, Tat, Nef, p17, RT, each capable of the induction of oxidative stress. (1) p17 may trigger the production of ROS through binding of redox active metal ions by its amyloidogenic assemblies [167]. (2) Nef may indirectly activate NADPH oxidase by activating the Vav/Rac/p21-activated kinase (PAK) signaling pathway involved in phagocytic NADPH oxidase activation and produce peroxynitrite [160]. (3) Tat induces oxidative action through several independent mechanisms via NADPH oxidase, spermine oxidase (SMO) induction and mitochondrial dysfunction [148]. (4) RT induces ROS through unknown mechanisms. There is ROS -dependent activation of the Twist [134], which regulates the expression of Nrf2, which stimulating the expression of antioxidant enzymes (HO1, Nqol1). In addition, the Twist regulates the expression of the Snail. Both transcription factors, Twist and Snail, are involved in epithelial to mesenchymal transduction (EMT). (5) Gp120 increases free radical production from monocyte-derived macrophages (MDM) inducing nitrogen oxide (NO). In astrocytes (AS), it enhances ROS production by several parallel mechanisms: via cytochrome P450 2E1 (CYP2E1), NOX2 and NOX4, and the Fenton-Weiss-Haber reaction. Multidrug resistance proteins (Mrps) involved in cellular defense against oxidative stress. Mrp4 (isoform of Mrp) involved in the regulation of ROS and it acts against ROS [156]. In neuroblastoma cells (NB) gp120 was shown to induce proline oxidase that produces pyroline-5-carboxylate with a concomitant generation of ROS [141]. Production of ROS, which damage of bystander cells inducing oxidative damage of DNA, proteins and lipids, apoptosis and inflammation. DNA damage drives genomic instability and promotes transformation of healthy cells, and propagation and dissemination of malignant cells [168]. Arrows indicate: purple arrows-secretion/entering the intercellular space; black arrows—relationships and interactions; red arrows—production of ROS; blue arrows-oxidative stress response. Text above arrows designates the processes leading to the production of ROS, and text below the arrows, forms of ROS.

\section{Oncogenic HIV-1 Proteins Inducing Oxidative Stress Are Found in the Extracellular Space \\ 7.1. Transactivator of Transcription}

Tat protein can be produced and released into the extracellular space by cells harboring actively replicating HIV-1 as well as by latently infected cells, with further uptake by the neighboring uninfected cells. Uptake of Tat would result in upregulation of inflammatory genes and cytotoxicity; this scenario was observed in a number of HIV-1 associated comorbidities, specifically, in neurocognitive disorders, cardiovascular impairment and accelerated aging [169]. Dangerously, the process may occur on the background of successful ART, in the absence of active HIV-1 replication and viral production. Considering that approximately $2 / 3$ of all Tat expressed by infected $T$ cells is secreted [170], the ac- 
tivities of Tat described above make a considerable contribution into HIV-1 associated pathologies [171,172].

Soluble Tat, in the absence of the virus, has been shown to cause induction of apoptosis, release of neurotransmitters, oxidative stress and inflammation [169]. Uptake of Tat has been shown to lead to activation of several transcription factors [173,174] including Sp1, $\mathrm{NF}-\mathrm{kB}$, and others, resulting in the modulation of expression of both HIV-1 and host genes, including pro-inflammatory cytokines (like TNF- $\alpha$, CCL2, IL-2, IL-6, and IL-8), adhesion molecules and sometimes, and pro- and anti-apoptotic factors [175-179], p53 and HPV oncoprotein E6 [107].

\subsection{Envelope Protein gp 120}

Envelope protein gp120 is known to be secreted by chronically infected cells [180,181], particularly from the intraepithelial immune cells even in presence of ART [98]. A subset of PLWH demonstrate persistent circulation in plasma of gp120 [182] and in saliva [98]. Moreover, gp120 was found in tissues of PLWH [183]. Brain cells can be directly exposed to gp120 secreted by infiltrated and infected microglia and astrocytes [127]. Gp120 is internalized by bystander cells through receptor-independent mechanisms [184]. Internalization of gp120 leads to the release of several proinflammatory, angiogenic, and lymphangiogenic factors from affected cells [185].

\subsection{Accessory Protein Negative Factor}

Accessory protein negative factor Nef is found in the serum of PLWH $[186,187]$. Nef can stimulate its own export via the release of extracellular vesicles (exosomes) from HIV-1 infected cells [188]. Of note, exosomes serve as a marker and confirmation of the systemic oxidative stress [189]. Secreted in exosomes, Nef triggers apoptosis in bystander cells. Extracellular Nef has deleterious effects on CD4+ T cells [188,190]; on bystander B cells by suppressing immunoglobulin class switching [191]; and on astrocytes [192] and endothelial cells [162].

\subsection{Reverse Transcriptase (RT)}

In our lab, we have shown secretion of RT into cell culture fluids of cells transiently expressing RT [114]. Recently, RT was also detected in the exosomes detected in the uterine of PLWH [193].

\subsection{Matrix Protein $p 17$}

Matrix protein p17 is continuously released into the extracellular space from HIV-1infected cells, and can be detected in the plasma of PLWH and in different organs and tissue specimens [138]. Cellular aspartyl proteases promote the unconventional secretion of biologically active p17 [194]. HIV-1 secretion of biologically active p17 takes place at the plasma membrane and occurs following its interaction with phosphatidylinositol$(4,5)$-bisphosphate and its subsequent cleavage from precursor Gag (Pr55Gag) by cellular aspartyl proteases [194]. Extracellularly, p17 deregulates the function of different cells involved in AIDS pathogenesis. Importantly, p17 accumulates and persists in different organs and tissues of PLWH on ART, even in the absence of any replicative activity $[136,195,196]$. These findings strongly suggest that p17 may be chronically present in HIV-1-I infected cells and tissues, even under ART-associated suppression of HIV-1 replication.

Thus, gp120 and Tat are actively secreted into the endothelial cell micro-environment, Nef can be neighboring uninfected cells including cells which cannot be infected with HIV1, modulating their metabolism, cell cycle progression, ability to differentiate, motility, and, importantly, the genomic stability, through induction of ROS. Some HIV-1 proteins such as matrix p17 and gp120 can accumulate and persist in lymphoid tissues for at least 1 year after the on-start of ART on the background of successful suppression of viral replication [196]. These proteins are involved in different processes associated with malignant transformation and tumor growth with significant direct and indirect adverse effects on the epithelial cells. 
These include a range of responses that contribute to endothelial dysfunction, including enhanced adhesiveness, permeability, cell proliferation, apoptosis, as well as activation of cytokine secretion [86], eventually leading to malignant transformation (Figure 3). In this respect, their effect would resemble oncogenesis mediated by known viral oncoproteins originating from EBV, HTLV-1, KSHV, HCV, HBV, HPV, and identified as causative agents of both AIDS-defining and non-AIDS defining forms of cancer.

\section{Conclusions}

People living with human immunodeficiency virus receiving antiretroviral therapy are characterized by high prevalence of different forms of cancer affecting epithelial cells. HIV-1 does not infect epithelial cells, however both HIV virions and proteins were shown to be sequestered into epithelial cells and affect their functions. These proteins have three specific properties:

- $\quad$ First, HIV proteins Tat, Nef, gp120, matrix protein p17, reverse transcriptase/RT induce oxidative stress with serious consequences in the form of DNA, protein and lipid damage, as well as changes in the intracellular signaling.

- Second, Tat, Nef, gp120, matrix protein p17, RT have a direct carcinogenic potential as demonstrated in the series of in vitro experiments and experiments in the laboratory animals.

- Third, Tat, Nef, gp120, matrix protein $\mathrm{p} 17$, reverse transcriptase/RT were shown to exit HIV expressing cells by different mechanisms, and, once present in the extracellular space, can be up-taken by innocent neighbor cells.

Sequestered/internalized by innocent bystander cells, these proteins modulate their metabolism, cell cycle progression, ability to differentiate, motility, redox balance (induce ROS) and genomic stability. Through this, they can trigger malignant transformation of normal cells. Another outcome is propagation (proliferation and dissemination) of already existing precancerous and cancer cells, and enhanced growth and metastatic activity of tumors expressing or exposed to HIV-1 proteins.

Altogether, we present a new mechanism of HIV-associated malignant transformation of epithelial cells driven by individual HIV proteins through the induction of reactive oxygen species. In this scenario, HIV-1 proteins act in a manner similar to the known viral oncogenes, and can cooperate with them promoting KSHV, EBV, HBV, HCV, and HPVassociated carcinogenesis. Such pathway of HIV associated carcinogenesis can co-occur together with carcinogenesis driven by persistent immune inflammation, and dysfunction of $B$ cells, $T$ cells and cellular components of the innate immune system.

Funding: This study was supported the Russian Fund for Basic Research grants 17_54_30002 and 20-04-01034 to M.I., Latvian Science Council grants LZP-2018/2-0308 and LZP-2020/2-0376 to M.I., and NCI R01CA 217715 to J.P. The work of Francesca Chiodi is supported by a grant from the Swedish Medical Research Council (Francesca Chiodi; Vetenskapsrådet 2019-01169).

Conflicts of Interest: The authors declare no conflict of interest.

\section{References}

1. Shiels, M.S.; Engels, E.A. Evolving epidemiology of HIV-associated malignancies. Curr. Opin. HIV AIDS 2017, 12, 6-11. [CrossRef] [PubMed]

2. Borrow, P. Innate immunity in acute HIV-1 infection. Curr. Opin. HIV AIDS 2011, 6, 353-363. [CrossRef] [PubMed]

3. Jenabian, M.A.; El-Far, M.; Vyboh, K.; Kema, I.; Costiniuk, C.T.; Thomas, R.; Baril, J.G.; LeBlanc, R.; Kanagaratham, C.; Radzioch, D.; et al. Immunosuppressive Tryptophan Catabolism and Gut Mucosal Dysfunction Following Early HIV Infection. J. Infect. Dis. 2015, 212, 355-366. [CrossRef] [PubMed]

4. Boasso, A.; Shearer, G.M.; Chougnet, C. Immune dysregulation in human immunodeficiency virus infection: Know it, fix it, prevent it? J. Intern. Med. 2009, 265, 78-96. [CrossRef]

5. Titanji, K.; Chiodi, F.; Bellocco, R.; Schepis, D.; Osorio, L.; Tassandin, C.; Tambussi, G.; Grutzmeier, S.; Lopalco, L.; De Milito, A. Primary HIV-1 infection sets the stage for important B lymphocyte dysfunctions. AIDS 2005, 19, 1947-1955. [CrossRef] 
6. De Milito, A.; Nilsson, A.; Titanji, K.; Thorstensson, R.; Reizenstein, E.; Narita, M.; Grutzmeier, S.; Sonnerborg, A.; Chiodi, F. Mechanisms of hypergammaglobulinemia and impaired antigen-specific humoral immunity in HIV-1 infection. Blood 2004, 103, 2180-2186. [CrossRef]

7. Amu, S.; Lantto Graham, R.; Bekele, Y.; Nasi, A.; Bengtsson, C.; Rethi, B.; Sorial, S.; Meini, G.; Zazzi, M.; Hejdeman, B.; et al. Dysfunctional phenotypes of CD4 + and CD8 + T cells are comparable in patients initiating ART during early or chronic HIV-1 infection. Medicine 2016, 95, e3738. [CrossRef]

8. Lemma, M.; Petkov, S.; Bekele, Y.; Petros, B.; Howe, R.; Chiodi, F. Profiling of Inflammatory Proteins in Plasma of HIV-1-Infected Children Receiving Antiretroviral Therapy. Proteomes 2020, 8, 24. [CrossRef]

9. Yang, X.; Su, B.; Zhang, X.; Liu, Y.; Wu, H.; Zhang, T. Incomplete immune reconstitution in HIV/AIDS patients on antiretroviral therapy: Challenges of immunological non-responders. J. Leukoc. Biol. 2020, 107, 597-612. [CrossRef]

10. Zicari, S.; Sessa, L.; Cotugno, N.; Ruggiero, A.; Morrocchi, E.; Concato, C.; Rocca, S.; Zangari, P.; Manno, E.C.; Palma, P. Immune Activation, Inflammation, and Non-AIDS Co-Morbidities in HIV-Infected Patients under Long-Term ART. Viruses 2019, 11, 200. [CrossRef]

11. Nabatanzi, R.; Cose, S.; Joloba, M.; Jones, S.R.; Nakanjako, D. Effects of HIV infection and ART on phenotype and function of circulating monocytes, natural killer, and innate lymphoid cells. AIDS Res. Ther. 2018, 15, 7. [CrossRef] [PubMed]

12. Amu, S.; Ruffin, N.; Rethi, B.; Chiodi, F. Impairment of B-cell functions during HIV-1 infection. AIDS 2013, 27, 2323-2334. [CrossRef] [PubMed]

13. Silverberg, M.J.; Lau, B.; Achenbach, C.J.; Jing, Y.; Althoff, K.N.; D’Souza, G.; Engels, E.A.; Hessol, N.A.; Brooks, J.T.; Burchell, A.N. Cumulative incidence of cancer among persons with HIV in North America: A cohort study. Ann. Intern. Med. 2015, 163, 507-518. [CrossRef] [PubMed]

14. Symons, J.; Chopra, A.; Malatinkova, E.; De Spiegelaere, W.; Leary, S.; Cooper, D.; Abana, C.O.; Rhodes, A.; Rezaei, S.D.; Vandekerckhove, L.; et al. HIV integration sites in latently infected cell lines: Evidence of ongoing replication. Retrovirology 2017, 14, 1-11. [CrossRef] [PubMed]

15. Schawkat, K.; Reiner, C.S. Diffuse liver disease: Cirrhosis, focal lesions in cirrhosis, and vascular liver disease. IDKD Springer Ser. 2018, 229-236.

16. Pinato, D.J.; Allara, E.; Chen, T.Y.; Trevisani, F.; Minguez, B.; Zoli, M.; Harris, M.; Dalla Pria, A.; Merchante, N.; Platt, H.; et al. Influence of HIV Infection on the Natural History of Hepatocellular Carcinoma: Results From a Global Multicohort Study. J. Clin. Oncol. 2019, 37, 296-304. [CrossRef]

17. Clifford, G.M.; Rickenbach, M.; Polesel, J.; Dal Maso, L.; Steffen, I.; Ledergerber, B.; Rauch, A.; Probst-Hensch, N.M.; Bouchardy, C.; Levi, F. Influence of HIV-related immunodeficiency on the risk of hepatocellular carcinoma. AIDS 2008, 22, 2135-2141. [CrossRef]

18. Pinato, D.J.; Dalla Pria, A.; Sharma, R.; Bower, M. Hepatocellular carcinoma: An evolving challenge in viral hepatitis and HIV coinfection. AIDS 2017, 31, 603-611. [CrossRef]

19. Gjærde, L.I.; Shepherd, L.; Jablonowska, E.; Lazzarin, A.; Rougemont, M.; Darling, K.; Battegay, M.; Braun, D.; Martel-Laferriere, V.; Lundgren, J.D. Trends in Incidences and Risk Factors for Hepatocellular Carcinoma and Other Liver Events in HIV and Hepatitis C Virus-coinfected Individuals From 2001 to 2014: A Multicohort Study. Clin. Infect. Dis. 2016, 63, 821-829. [CrossRef]

20. Joshi, D.; O'Grady, J.; Dieterich, D.; Gazzard, B.; Agarwal, K. Increasing burden of liver disease in patients with HIV infection. Lancet 2011, 377, 1198-1209. [CrossRef]

21. Brenchley, J.M.; Price, D.A.; Schacker, T.W.; Asher, T.E.; Silvestri, G.; Rao, S.; Kazzaz, Z.; Bornstein, E.; Lambotte, O.; Altmann, D.; et al. Microbial translocation is a cause of systemic immune activation in chronic HIV infection. Nat. Med. 2006, 12, 1365-1371. [CrossRef] [PubMed]

22. Marchetti, G.; Tincati, C.; Silvestri, G. Microbial translocation in the pathogenesis of HIV infection and AIDS. Clin. Microbiol. Rev. 2013, 26, 2-18. [CrossRef] [PubMed]

23. Soares, J.B.; Pimentel-Nunes, P.; Roncon-Albuquerque, R.; Leite-Moreira, A. The role of lipopolysaccharide/toll-like receptor 4 signaling in chronic liver diseases. Hepatol. Int. 2010, 4, 659-672. [CrossRef] [PubMed]

24. Ramendra, R.; Isnard, S.; Mehraj, V.; Chen, J.; Zhang, Y.; Finkelman, M.; Routy, J.P. Circulating LPS and (1->3)-beta-D-Glucan: A Folie a Deux Contributing to HIV-Associated Immune Activation. Front. Immunol. 2019, 10, 465. [CrossRef] [PubMed]

25. Kovari, H.; Ledergerber, B.; Battegay, M.; Rauch, A.; Hirschel, B.; Foguena, A.K.; Vernazza, P.; Bernasconi, E.; Mueller, N.J.; Weber, R. Incidence and risk factors for chronic elevation of alanine aminotransferase levels in HIV-infected persons without hepatitis b or c virus co-infection. Clin. Infect. Dis. 2010, 50, 502-511. [CrossRef] [PubMed]

26. Crane, M.; Visvanathan, K.; Lewin, S.R. HIV Infection and TLR Signalling in the Liver. Gastroenterol. Res. Pr. 2012, $2012,473925$. [CrossRef] [PubMed]

27. Iser, D.M.; Warner, N.; Revill, P.A.; Solomon, A.; Wightman, F.; Saleh, S.; Crane, M.; Cameron, P.U.; Bowden, S.; Nguyen, T.; et al. Coinfection of hepatic cell lines with human immunodeficiency virus and hepatitis B virus leads to an increase in intracellular hepatitis B surface antigen. J. Virol. 2010, 84, 5860-5867. [CrossRef]

28. Ganesan, M.; Poluektova, L.Y.; Kharbanda, K.K.; Osna, N.A. Liver as a target of human immunodeficiency virus infection. World J. Gastroenterol. 2018, 24, 4728-4737. [CrossRef]

29. Kandathil, A.; Durand, C.; Quinn, J.; Cameron, A.; Thomas, D.; Balagopal, A. Liver macrophages and HIV-1 persistence. In Proceedings of the CROI, Seattle, WA, USA, 23-26 February 2015. 
30. Chew, K.W.; Bhattacharya, D. Virologic and immunologic aspects of HIV-hepatitis C virus coinfection. AIDS 2016, 30, 2395-2404. [CrossRef]

31. Lin, W.; Weinberg, E.M.; Chung, R.T. Pathogenesis of accelerated fibrosis in HIV/HCV co-infection. J. Infect. Dis. 2013, 207, S13-S18. [CrossRef]

32. Hong, F.; Saiman, Y.; Si, C.; Mosoian, A.; Bansal, M.B. X4 Human immunodeficiency virus type 1 gp120 promotes human hepatic stellate cell activation and collagen I expression through interactions with CXCR4. PLoS ONE 2012, 7, e33659. [CrossRef] [PubMed]

33. Mosoian, A.; Zhang, L.; Hong, F.; Cunyat, F.; Rahman, A.; Bhalla, R.; Panchal, A.; Saiman, Y.; Fiel, M.I.; Florman, S.; et al. Frontline Science: HIV infection of Kupffer cells results in an amplified proinflammatory response to LPS. J. Leukoc. Biol. 2017, 101, 1083-1090. [CrossRef] [PubMed]

34. Tuyama, A.C.; Hong, F.; Saiman, Y.; Wang, C.; Ozkok, D.; Mosoian, A.; Chen, P.; Chen, B.K.; Klotman, M.E.; Bansal, M.B. Human immunodeficiency virus (HIV)-1 infects human hepatic stellate cells and promotes collagen I and monocyte chemoattractant protein-1 expression: Implications for the pathogenesis of HIV/hepatitis C virus-induced liver fibrosis. Hepatology 2010, 52, 612-622. [CrossRef] [PubMed]

35. Lin, W.; Wu, G.; Li, S.; Weinberg, E.M.; Kumthip, K.; Peng, L.F.; Mendez-Navarro, J.; Chen, W.C.; Jilg, N.; Zhao, H.; et al. HIV and HCV cooperatively promote hepatic fibrogenesis via induction of reactive oxygen species and NFkappaB. J. Biol. Chem. 2011, 286, 2665-2674. [CrossRef] [PubMed]

36. Herrera, S.; Martinez-Sanz, J.; Serrano-Villar, S. HIV, Cancer, and the Microbiota: Common Pathways Influencing Different Diseases. Front. Immunol. 2019, 10, 1466. [CrossRef]

37. Koziel, M.J.; Peters, M.G. Viral hepatitis in HIV infection. N. Engl. J. Med. 2007, 356, 1445-1454. [CrossRef]

38. Sun, H.Y.; Sheng, W.H.; Tsai, M.S.; Lee, K.Y.; Chang, S.Y.; Hung, C.C. Hepatitis B virus coinfection in human immunodeficiency virus-infected patients: A review. World J. Gastroenterol. 2014, 20, 14598-14614. [CrossRef]

39. Garcia-Samaniego, J.; Rodriguez, M.; Berenguer, J.; Rodriguez-Rosado, R.; Carbo, J.; Asensi, V.; Soriano, V. Hepatocellular carcinoma in HIV-infected patients with chronic hepatitis C. Am. J. Gastroenterol. 2001, 96, 179-183. [CrossRef]

40. Nabih, H.K. The Significance of HCV Viral Load in the Incidence of HCC: A Correlation Between Mir-122 and CCL2. J. Gastrointest. Cancer 2020, 51, 412-417. [CrossRef]

41. Lemon, S.M.; McGivern, D.R. Is hepatitis C virus carcinogenic? Gastroenterology 2012, 142, 1274-1278. [CrossRef]

42. Ivanov, A.V.; Valuev-Elliston, V.T.; Tyurina, D.A.; Ivanova, O.N.; Kochetkov, S.N.; Bartosch, B.; Isaguliants, M.G. Oxidative stress, a trigger of hepatitis C and B virus-induced liver carcinogenesis. Oncotarget 2017, 8, 3895. [CrossRef] [PubMed]

43. Hall, J.; Short, S. Management of glioblastoma multiforme in HIV patients: A case series and review of published studies. Clin. Oncol. 2009, 21, 591-597. [CrossRef] [PubMed]

44. Del Valle, L.; Piña-Oviedo, S. HIV disorders of the brain: Pathology and pathogenesis. Front. Biosci. 2006, 11, 718-732. [CrossRef] [PubMed]

45. Cedeno-Laurent, F.; Trujillo, J.R. Gliomas and brain lymphomas in HIV-1/AIDS patients: Reflections from a 20-year follow up in Mexico and Brazil. Microbiol. Res. 2011, 2, 11. [CrossRef]

46. Patel, A.P.; Fisher, J.L.; Nichols, E.; Abd-Allah, F.; Abdela, J.; Abdelalim, A.; Abraha, H.N.; Agius, D.; Alahdab, F.; Alam, T. Global, regional, and national burden of brain and other CNS cancer, 1990-2016: A systematic analysis for the Global Burden of Disease Study 2016. Lancet Neurol. 2019, 18, 376-393. [CrossRef]

47. Choy, W.; Lagman, C.; Lee, S.J.; Bui, T.T.; Safaee, M.; Yang, I. Impact of human immunodeficiency virus in the pathogenesis and outcome of patients with glioblastoma multiforme. Brain Tumor Res. Treat. 2016, 4, 77-86. [CrossRef]

48. Acevedo, N.; Pillai, C.; Welch, M. HCP-01diagnosis and management of high-grade glioma in patients with HIV. Neuro Oncol. 2015, 17, v101. [CrossRef]

49. Tacconi, L.; Stapleton, S.; Signorelli, F.; Thomas, D. Acquired immune deficiency syndrome (AIDS) and cerebral astrocytoma. Clin. Neurol. Neurosurg. 1996, 98, 149-151. [CrossRef]

50. Chamberlain, M.C. Gliomas in patients with acquired immune deficiency syndrome. Cancer 1994, 74, 1912-1914. [CrossRef]

51. Wolff, R.; Zimmermann, M.; Marquardt, G.; Lanfermann, H.; Nafe, R.; Seifert, V. Glioblastoma multiforme of the brain stem in a patient with aquired immunodeficiency syndrome. Acta Neurochir. 2002, 144, 941-945. [CrossRef]

52. Chiodi, F.; Fuerstenberg, S.; Gidlund, M.; Asjo, B.; Fenyo, E.M. Infection of brain-derived cells with the human immunodeficiency virus. J. Virol. 1987, 61, 1244-1247. [CrossRef] [PubMed]

53. Messam, C.A.; Major, E.O. Stages of restricted HIV-1 infection in astrocyte cultures derived from human fetal brain tissue. J. Neurovirol. 2000, 6, S90-S94. [PubMed]

54. Robbins, H.A.; Shiels, M.S.; Pfeiffer, R.M.; Engels, E.A. Epidemiologic contributions to recent cancer trends among HIV-infected people in the United States. AIDS 2014, 28, 881-890. [CrossRef]

55. Palefsky, J.M. HPV-associated anal and cervical cancers in HIV-infected individuals: Incidence and prevention in the antiretroviral therapy era. Curr. Opin. HIV AIDS 2017, 12, 26. [CrossRef] [PubMed]

56. Osazuwa-Peters, N.; Massa, S.T.; Simpson, M.C.; Adjei Boakye, E.; Varvares, M.A. Survival of human papillomavirus-associated cancers: Filling in the gaps. Cancer 2018, 124, 18-20. [CrossRef] 
57. Strickler, H.D.; Burk, R.D.; Fazzari, M.; Anastos, K.; Minkoff, H.; Massad, L.S.; Hall, C.; Bacon, M.; Levine, A.M.; Watts, D.H. Natural history and possible reactivation of human papillomavirus in human immunodeficiency virus-positive women. J. Natl. Cancer Inst. 2005, 97, 577-586. [CrossRef]

58. Clarke, B.; Chetty, R. Postmodern cancer: The role of human immunodeficiency virus in uterine cervical cancer. Mol. Pathol. 2002, 55, 19-24. [CrossRef] [PubMed]

59. Palefsky, J. Biology of HPV in HIV infection. Adv. Dent. Res. 2006, 19, 99-105. [CrossRef]

60. Palefsky, J.M.; Holly, E.A. Chapter 6: Immunosuppression and co-infection with HIV. J. Natl. Cancer Inst. Monogr. 2003, 2003, 41-46. [CrossRef]

61. Chambuso, R.; Gray, C.M.; Kaambo, E.; Rebello, G.; Ramesar, R. Impact of Host Molecular Genetic Variations and HIV/HPV Co-infection on Cervical Cancer Progression: A Systematic review. Oncomedicine 2018, 3, 82-93. [CrossRef]

62. Joag, S.V.; Adany, I.; Li, Z.; Foresman, L.; Pinson, D.M.; Wang, C.; Stephens, E.B.; Raghavan, R.; Narayan, O. Animal model of mucosally transmitted human immunodeficiency virus type 1 disease: Intravaginal and oral deposition of simian/human immunodeficiency virus in macaques results in systemic infection, elimination of CD4+ T cells, and AIDS. J. Virol. 1997, 71, 4016-4023. [CrossRef] [PubMed]

63. Bosch, M.L.; Schmidt, A.; Agy, M.B.; Kimball, L.E.; Morton, W.R. Infection of Macaca nemestrina neonates with HIV-1 via different routes of inoculation. AIDS 1997, 11, 1555-1563. [CrossRef] [PubMed]

64. Carias, A.M.; McCoombe, S.; McRaven, M.; Anderson, M.; Galloway, N.; Vandergrift, N.; Fought, A.J.; Lurain, J.; Duplantis, M.; Veazey, R.S. Defining the interaction of HIV-1 with the mucosal barriers of the female reproductive tract. J. Virol. 2013, 87, 11388-11400. [CrossRef] [PubMed]

65. Girard, M.; Mahoney, J.; Wei, Q.; Van Der Ryst, E.; Muchmore, E.; Barré-Sinoussi, F.; Fultz, P.N. Genital infection of female chimpanzees with human immunodeficiency virus type 1. AIDS Res. Hum. Retrovir. 1998, 14, 1357-1367. [CrossRef]

66. Dinh, M.H.; Anderson, M.R.; McRaven, M.D.; Cianci, G.C.; McCoombe, S.G.; Kelley, Z.L.; Gioia, C.J.; Fought, A.J.; Rademaker, A.W.; Veazey, R.S.; et al. Visualization of HIV-1 interactions with penile and foreskin epithelia: Clues for female-to-male HIV transmission. PLoS Pathog. 2015, 11, e1004729. [CrossRef] [PubMed]

67. Ganor, Y.; Zhou, Z.; Tudor, D.; Schmitt, A.; Vacher-Lavenu, M.C.; Gibault, L.; Thiounn, N.; Tomasini, J.; Wolf, J.P.; Bomsel, M Within $1 \mathrm{~h}, \mathrm{HIV}-1$ uses viral synapses to enter efficiently the inner, but not outer, foreskin mucosa and engages Langerhans-T cell conjugates. Mucosal Immunol. 2010, 3, 506-522. [CrossRef]

68. Hladik, F.; Sakchalathorn, P.; Ballweber, L.; Lentz, G.; Fialkow, M.; Eschenbach, D.; McElrath, M.J. Initial events in establishing vaginal entry and infection by human immunodeficiency virus type-1. Immunity 2007, 26, 257-270. [CrossRef]

69. Maher, D.; Wu, X.; Schacker, T.; Horbul, J.; Southern, P. HIV binding, penetration, and primary infection in human cervicovaginal tissue. Proc. Natl. Acad. Sci. USA 2005, 102, 11504-11509. [CrossRef]

70. Stoddard, E.; Ni, H.; Cannon, G.; Zhou, C.; Kallenbach, N.; Malamud, D.; Weissman, D. gp340 promotes transcytosis of human immunodeficiency virus type 1 in genital tract-derived cell lines and primary endocervical tissue. J. Virol. 2009, 83, 8596-8603 [CrossRef]

71. Zhou, Z.; De Longchamps, N.B.; Schmitt, A.; Zerbib, M.; Vacher-Lavenu, M.-C.; Bomsel, M.; Ganor, Y. HIV-1 efficient entry in inner foreskin is mediated by elevated CCL5/RANTES that recruits T cells and fuels conjugate formation with Langerhans cells. PLoS Pathog. 2011, 7, e1002100. [CrossRef]

72. Liu, R.; Huang, L.; Li, J.; Zhou, X.; Zhang, H.; Zhang, T.; Lei, Y.; Wang, K.; Xie, N.; Zheng, Y.; et al. HIV Infection in gastric epithelial cells. J. Infect. Dis. 2013, 208, 1221-1230. [CrossRef] [PubMed]

73. Dorosko, S.M.; Connor, R.I. Primary human mammary epithelial cells endocytose HIV-1 and facilitate viral infection of CD4+ T lymphocytes. J. Virol. 2010, 84, 10533-10542. [CrossRef] [PubMed]

74. Hughes, K.; Akturk, G.; Gnjatic, S.; Chen, B.; Klotman, M.; Blasi, M. Proliferation of HIV-infected renal epithelial cells following virus acquisition from infected macrophages. AIDS 2020, 34, 1581-1591. [CrossRef] [PubMed]

75. Brune, K.A.; Ferreira, F.; Mandke, P.; Chau, E.; Aggarwal, N.R.; D'Alessio, F.R.; Lambert, A.A.; Kirk, G.; Blankson, J.; Drummond, M.B.; et al. HIV Impairs Lung Epithelial Integrity and Enters the Epithelium to Promote Chronic Lung Inflammation. PLoS ONE 2016, 11, e0149679. [CrossRef]

76. Wagner, T.A.; McLaughlin, S.; Garg, K.; Cheung, C.Y.; Larsen, B.B.; Styrchak, S.; Huang, H.C.; Edlefsen, P.T.; Mullins, J.I.; Frenkel, L.M. HIV latency. Proliferation of cells with HIV integrated into cancer genes contributes to persistent infection. Science 2014, 345, 570-573. [CrossRef]

77. Fan, H.; Johnson, C. Insertional oncogenesis by non-acute retroviruses: Implications for gene therapy. Viruses 2011, 3, 398-422. [CrossRef]

78. Maldarelli, F. The role of HIV integration in viral persistence: No more whistling past the proviral graveyard. J. Clin. Investig. 2016, 126, 438-447. [CrossRef]

79. Asin, S.N.; Wildt-Perinic, D.; Mason, S.I.; Howell, A.L.; Wira, C.R.; Fanger, M.W. Human immunodeficiency virus type 1 infection of human uterine epithelial cells: Viral shedding and cell contact-mediated infectivity. J. Infect. Dis. 2003, 187, 1522-1533. [CrossRef]

80. Aiken, C. Pseudotyping human immunodeficiency virus type 1 (HIV-1) by the glycoprotein of vesicular stomatitis virus targets HIV-1 entry to an endocytic pathway and suppresses both the requirement for Nef and the sensitivity to cyclosporin A. J. Virol. 1997, 71, 5871-5877. [CrossRef] 
81. King, B.; Daly, J. Pseudotypes: Your flexible friends. Futur. Microbiol. 2014, 9, 135-137. [CrossRef]

82. Tang, Y.; George, A.; Nouvet, F.; Sweet, S.; Emeagwali, N.; Taylor, H.E.; Simmons, G.; Hildreth, J.E. Infection of female primary lower genital tract epithelial cells after natural pseudotyping of HIV-1: Possible implications for sexual transmission of HIV-1. PLoS ONE 2014, 9, e101367. [CrossRef]

83. Tang, Y.; Woodward, B.O.; Pastor, L.; George, A.M.; Petrechko, O.; Nouvet, F.J.; Haas, D.W.; Jiang, G.; Hildreth, J.E.K. Endogenous Retroviral Envelope Syncytin Induces HIV-1 Spreading and Establishes HIV Reservoirs in Placenta. Cell Rep. 2020, 30, 4528-4539. [CrossRef] [PubMed]

84. Grandi, N.; Tramontano, E. Type W Human Endogenous Retrovirus (HERV-W) Integrations and Their Mobilization by L1 Machinery: Contribution to the Human Transcriptome and Impact on the Host Physiopathology. Viruses 2017, 9, 162. [CrossRef] [PubMed]

85. Devadoss, D.; Singh, S.P.; Acharya, A.; Do, K.C.; Periyasamy, P.; Manevski, M.; Mishra, N.; Tellez, C.; Ramakrishnan, S.; Belinsky, S. Lung Bronchial Epithelial Cells are HIV Targets for Proviral Genomic Integration. bioRxiv 2020. [CrossRef]

86. Anand, A.R.; Rachel, G.; Parthasarathy, D. HIV Proteins and Endothelial Dysfunction: Implications in Cardiovascular Disease. Front. Cardiovasc. Med. 2018, 5, 185. [CrossRef]

87. De Paoli, P.; Carbone, A. Microenvironmental abnormalities induced by viral cooperation: Impact on lymphomagenesis. Semin. Cancer Biol. 2015, 34, 70-80. [CrossRef]

88. Mazzuca, P.; Caruso, A.; Caccuri, F. Endothelial Cell Dysfunction in HIV-1 Infection. Endothel. Dysfunct. Old Concepts New Chall. 2018, 347. [CrossRef]

89. Liapis, K.; Clear, A.; Owen, A.; Coutinho, R.; Greaves, P.; Lee, A.M.; Montoto, S.; Calaminici, M.; Gribben, J.G. The microenvironment of AIDS-related diffuse large B-cell lymphoma provides insight into the pathophysiology and indicates possible therapeutic strategies. Blood 2013, 122, 424-433. [CrossRef]

90. Taylor, J.G.; Liapis, K.; Gribben, J.G. The role of the tumor microenvironment in HIV-associated lymphomas. Biomark. Med. 2015, 9, 473-482. [CrossRef]

91. Liu, Y.; Gaisa, M.M.; Wang, X.; Swartz, T.H.; Arens, Y.; Dresser, K.A.; Sigel, C.; Sigel, K. Differences in the Immune Microenvironment of Anal Cancer Precursors by HIV Status and Association With Ablation Outcomes. J. Infect. Dis. 2018, 217, 703-709. [CrossRef]

92. Paiardini, M.; Frank, I.; Pandrea, I.; Apetrei, C.; Silvestri, G. Mucosal immune dysfunction in AIDS pathogenesis. AIDS Rev. 2008, 10, 36-46. [PubMed]

93. Yaghoobi, M.; Le Gouvello, S.; Aloulou, N.; Duprez-Dutreuil, C.; Walker, F.; Sobhani, I. FoxP3 overexpression and CD1a+ and $\mathrm{CD} 3+$ depletion in anal tissue as possible mechanisms for increased risk of human papillomavirus-related anal carcinoma in HIV infection. Color. Dis. 2011, 13, 768-773. [CrossRef] [PubMed]

94. Guimaraes, A.G.; da Costa, A.G.; Martins-Filho, O.A.; Pimentel, J.P.; Zauli, D.A.; Peruhype-Magalhaes, V.; Teixeira-Carvalho, A.; Bela, S.R.; Xavier, M.A.; Coelho-Dos-Reis, J.G.; et al. CD11c + CD123Low dendritic cell subset and the triad TNF-alpha/IL17A/IFN-gamma integrate mucosal and peripheral cellular responses in HIV patients with high-grade anal intraepithelial neoplasia: A systems biology approach. JAIDS J. Acquir. Immune Defic. Syndr. 2015, 68, 112-122. [CrossRef] [PubMed]

95. Micsenyi, A.M.; Zony, C.; Alvarez, R.A.; Durham, N.D.; Chen, B.K.; Klotman, M.E. Postintegration HIV-1 infection of cervical epithelial cells mediates contact-dependent productive infection of T cells. J. Infect. Dis. 2013, 208, 1756-1767. [CrossRef] [PubMed]

96. Yasen, A.; Herrera, R.; Rosbe, K.; Lien, K.; Tugizov, S.M. HIV internalization into oral and genital epithelial cells by endocytosis and macropinocytosis leads to viral sequestration in the vesicles. Virology 2018, 515, 92-107. [CrossRef]

97. Tugizov, S.M. Human immunodeficiency virus interaction with oral and genital mucosal epithelia may lead to epithelialmesenchymal transition and sequestration of virions in the endosomal compartments. Oral Dis. 2020, 26, 40-46. [CrossRef] [PubMed]

98. Tugizov, S.M.; Herrera, R.; Chin-Hong, P.; Veluppillai, P.; Greenspan, D.; Michael Berry, J.; Pilcher, C.D.; Shiboski, C.H.; Jay, N.; Rubin, M.; et al. HIV-associated disruption of mucosal epithelium facilitates paracellular penetration by human papillomavirus. Virology 2013, 446, 378-388. [CrossRef] [PubMed]

99. Parvez, M.K. HBV and HIV co-infection: Impact on liver pathobiology and therapeutic approaches. World J. Hepatol. 2015, 7, 121-126. [CrossRef] [PubMed]

100. Park, I.W.; Fan, Y.; Luo, X.; Ryou, M.G.; Liu, J.; Green, L.; He, J.J. HIV-1 Nef is transferred from expressing T cells to hepatocytic cells through conduits and enhances HCV replication. PLoS ONE 2014, 9, e99545. [CrossRef] [PubMed]

101. Luedde, T.; Schwabe, R.F. NF-kappaB in the liver-Linking injury, fibrosis and hepatocellular carcinoma. Nat. Rev. Gastroenterol. Hepatol. 2011, 8, 108-118. [CrossRef] [PubMed]

102. McGivern, D.R.; Lemon, S.M. Tumor suppressors, chromosomal instability, and hepatitis $C$ virus-associated liver cancer. Annu. Rev. Pathol. Mech. Dis. 2009, 4, 399-415. [CrossRef] [PubMed]

103. Tugizov, S.M.; Herrera, R.; Veluppillai, P.; Greenspan, D.; Palefsky, J.M. 46. HIV-induced epithelial-mesenchymal transition in mucosal epithelium facilitates HPV paracellular penetration. Sex. Health 2013, 10, 592. [CrossRef]

104. Tornesello, M.L.; Buonaguro, F.M.; Beth-Giraldo, E.; Giraldo, G. Human immunodeficiency virus type 1 tat gene enhances human papillomavirus early gene expression. Intervirology 1993, 36, 57-64. [CrossRef] 
105. Buonaguro, F.M.; Tornesello, M.L.; Buonaguro, L.; Del Gaudio, E.; Beth-Giraldo, E.; Giraldo, G. Role of HIV as Cofactor in HPV Oncogenesis: In Vitro Evidences of Virus Interactions. In Advanced Technologies in Research, Diagnosis and Treatment of AIDS and in Oncology; Karger Publishers: Basel, Switzerland, 1994; Volume 46, pp. 102-109.

106. Kim, R.H.; Yochim, J.M.; Kang, M.K.; Shin, K.-H.; Christensen, R.; Park, N.-H. HIV-1 Tat enhances replicative potential of human oral keratinocytes harboring HPV-16 genome. Int. J. Oncol. 1992, 33, 777-782. [CrossRef]

107. Barillari, G.; Palladino, C.; Bacigalupo, I.; Leone, P.; Falchi, M.; Ensoli, B. Entrance of the Tat protein of HIV-1 into human uterine cervical carcinoma cells causes upregulation of HPV-E6 expression and a decrease in p53 protein levels. Oncol. Lett. 2016, 12, 2389-2394. [CrossRef]

108. Vernon, S.D.; Hart, C.E.; Reeves, W.C.; Icenogle, J.P. The HIV-1 tat protein enhances E2-dependent human papillomavirus 16 transcription. Virus Res. 1993, 27, 133-145. [CrossRef]

109. Barillari, G.; Ensoli, B. Angiogenic effects of extracellular human immunodeficiency virus type 1 Tat protein and its role in the pathogenesis of AIDS-associated Kaposi's sarcoma. Clin. Microbiol. Rev. 2002, 15, 310-326. [CrossRef] [PubMed]

110. Krill, L.S.; Tewari, K.S. Exploring the therapeutic rationale for angiogenesis blockade in cervical cancer. Clin. Ther. 2015, 37, 9-19. [CrossRef]

111. Nyagol, J.; Leucci, E.; Omnis, A.; De Falco, G.; Tigli, C.; Sanseverino, F.; Torriccelli, M.; Palummo, N.; Pacenti, L.; Santopietro, R. The effects of HIV-1 Tat protein on cell cycle during cervical carcinogenesis. Cancer Biol. Ther. 2006, 5, 684-690. [CrossRef] [PubMed]

112. Bayurova, E. (Gamaleya Research Center for Epidemiology and Microbiology, M.P. Chumakov Federal Scientific Center for Research and Development of Immune-and-Biological Products of Russian Academy of Sciences, Moscow, Russia); Isaguliants, M. (Gamaleya Research Center for Epidemiology and Microbiology; M.P. Chumakov Federal Scientific Center for Research and Development of Immune-and-Biological Products of Russian Academy of Sciences; Department of Microbiology, Tumor and Cell Biology, Karolinska Institutet; Department of Research, Riga Stradins University, Riga, Latvia); Tugizov, S. (Department of Medicine, University of California, San Francisco, CA, USA); Palefsky, J. (Department of Medicine, University of California, San Francisco, CA, USA). Personal communication, 2020.

113. Collini, P.J.; Bewley, M.A.; Mohasin, M.; Marriott, H.M.; Miller, R.F.; Geretti, A.M.; Beloukas, A.; Papadimitropoulos, A.; Read, R.C.; Noursadeghi, M.; et al. HIV gp120 in the Lungs of Antiretroviral Therapy-treated Individuals Impairs Alveolar Macrophage Responses to Pneumococci. Am. J. Respir. Crit. Care Med. 2018, 197, 1604-1615. [CrossRef]

114. Latanova, A.; Petkov, S.; Kuzmenko, Y.; Kilpelainen, A.; Ivanov, A.; Smirnova, O.; Krotova, O.; Korolev, S.; Hinkula, J.; Karpov, V.; et al. Fusion to Flaviviral Leader Peptide Targets HIV-1 Reverse Transcriptase for Secretion and Reduces Its Enzymatic Activity and Ability to Induce Oxidative Stress but Has No Major Effects on Its Immunogenic Performance in DNA-Immunized Mice. J. Immunol. Res. 2017, 2017, 7407136. [CrossRef] [PubMed]

115. Lien, K.; Mayer, W.; Herrera, R.; Rosbe, K.; Tugizov, S.M. HIV-1 proteins gp120 and tat induce the epithelial-mesenchymal transition in oral and genital mucosal epithelial cells. PLoS ONE 2019, 14, e0226343. [CrossRef] [PubMed]

116. Jansons, J.; Bayurova, E.; Skrastina, D.; Kurlanda, A.; Fridrihsone, I.; Kostyushev, D.; Kostyusheva, A.; Artyuhov, A.; Dashinimaev, E.; Avdoshina, D. Expression of the Reverse Transcriptase Domain of Telomerase Reverse Transcriptase Induces Lytic Cellular Response in DNA-Immunized Mice and Limits Tumorigenic and Metastatic Potential of Murine Adenocarcinoma 4T1 Cells. Vaccines 2020, 8, 318. [CrossRef]

117. Wechsler, E.I.; Tugizov, S.; Herrera, R.; Da Costa, M.; Palefsky, J.M. E5 can be expressed in anal cancer and leads to epidermal growth factor receptor-induced invasion in a human papillomavirus 16-transformed anal epithelial cell line. J. Gen. Virol. 2018, 99, 631-644. [CrossRef] [PubMed]

118. Aerts, J.L.; Gonzales, M.I.; Topalian, S.L. Selection of appropriate control genes to assess expression of tumor antigens using real-time RT-PCR. BioTechniques 2004, 36, 84-86, 88, 90-91. [CrossRef]

119. Huynh, D.; Vincan, E.; Mantamadiotis, T.; Purcell, D.; Chan, C.-K.; Ramsay, R. Oncogenic properties of HIV-Tat in colorectal cancer cells. Curr. HIV Res. 2007, 5, 403-409. [CrossRef]

120. Liu, Y.P.; Chen, C.H.; Yen, C.H.; Tung, C.W.; Chen, C.J.; Chen, Y.A.; Huang, M.S. Human immunodeficiency virus Tat-TIP30 interaction promotes metastasis by enhancing the nuclear translocation of Snail in lung cancer cell lines. Cancer Sci. 2018, 109, 3105-3114. [CrossRef]

121. Mani, K.; Sandgren, S.; Lilja, J.; Cheng, F.; Svensson, K.; Persson, L.; Belting, M. HIV-Tat protein transduction domain specifically attenuates growth of polyamine deprived tumor cells. Mol. Cancer Ther. 2007, 6, 782-788. [CrossRef]

122. Dandachi, D.; Moron, F. Effects of HIV on the Tumor Microenvironment. Adv. Exp. Med. Biol. 2020, 1263, 45-54. [CrossRef]

123. Nunnari, G.; Smith, J.A.; Daniel, R. HIV-1 Tat and AIDS-associated cancer: Targeting the cellular anti-cancer barrier? J. Exp. Clin. Cancer Res. 2008, 27, 3. [CrossRef]

124. Loarca, L.; Fraietta, J.A.; Pirrone, V.; Szep, Z.; Wigdahl, B. Human immunodeficiency and Virus (HIV) Infection and Cancer. HIV/AIDS Contemp. Chall. 2017, 1. [CrossRef]

125. Srivastava, D.K.; Tendler, C.L.; Milani, D.; English, M.A.; Licht, J.D.; Wilson, S.H. The HIV-1 transactivator protein Tat is a potent inducer of the human DNA repair enzyme beta-polymerase. AIDS 2001, 15, 433-440. [CrossRef] [PubMed]

126. Chipitsyna, G.; Slonina, D.; Siddiqui, K.; Peruzzi, F.; Skorski, T.; Reiss, K.; Sawaya, B.E.; Khalili, K.; Amini, S. HIV-1 Tat increases cell survival in response to cisplatin by stimulating Rad51 gene expression. Oncogene 2004, 23, 2664-2671. [CrossRef] [PubMed] 
127. Valentin-Guillama, G.; Lopez, S.; Kucheryavykh, Y.V.; Chorna, N.E.; Perez, J.; Ortiz-Rivera, J.; Inyushin, M.; Makarov, V.; Valentin-Acevedo, A.; Quinones-Hinojosa, A.; et al. HIV-1 Envelope Protein gp120 Promotes Proliferation and the Activation of Glycolysis in Glioma Cell. Cancers 2018, 10, 301. [CrossRef] [PubMed]

128. Warburg, O. On the origin of cancer cells. Science 1956, 123, 309-314. [CrossRef] [PubMed]

129. Gatenby, R.A.; Gillies, R.J. Why do cancers have high aerobic glycolysis? Nat. Rev. Cancer 2004, 4, 891-899. [CrossRef]

130. Yuan, Z.; Petree, J.R.; Lee, F.E.; Fan, X.; Salaita, K.; Guidot, D.M.; Sadikot, R.T. Macrophages exposed to HIV viral protein disrupt lung epithelial cell integrity and mitochondrial bioenergetics via exosomal microRNA shuttling. Cell Death Dis. 2019, 10, 580. [CrossRef]

131. Greenway, A.L.; McPhee, D.A.; Allen, K.; Johnstone, R.; Holloway, G.; Mills, J.; Azad, A.; Sankovich, S.; Lambert, P. Human immunodeficiency virus type $1 \mathrm{Nef}$ binds to tumor suppressor p53 and protects cells against p53-mediated apoptosis. J. Virol. 2002, 76, 2692-2702. [CrossRef]

132. Xue, M.; Yao, S.; Hu, M.; Li, W.; Hao, T.; Zhou, F.; Zhu, X.; Lu, H.; Qin, D.; Yan, Q.; et al. HIV-1 Nef and KSHV oncogene K1 synergistically promote angiogenesis by inducing cellular miR-718 to regulate the PTEN/AKT/mTOR signaling pathway. Nucleic Acids Res. 2014, 42, 9862-9879. [CrossRef]

133. Santerre, M.; Chatila, W.; Wang, Y.; Mukerjee, R.; Sawaya, B.E. HIV-1 Nef promotes cell proliferation and microRNA dysregulation in lung cells. Cell Cycle 2019, 18, 130-142. [CrossRef]

134. Bayurova, E.; Jansons, J.; Skrastina, D.; Smirnova, O.; Mezale, D.; Kostyusheva, A.; Kostyushev, D.; Petkov, S.; Podschwadt, P.; Valuev-Elliston, V. HIV-1 Reverse Transcriptase Promotes Tumor Growth and Metastasis Formation via ROS-Dependent Upregulation of Twist. Oxidative Med. Cell. Longev. 2019, 2019, 1-28. [CrossRef] [PubMed]

135. Giagulli, C.; Magiera, A.K.; Bugatti, A.; Caccuri, F.; Marsico, S.; Rusnati, M.; Vermi, W.; Fiorentini, S.; Caruso, A. HIV-1 matrix protein p17 binds to the IL-8 receptor CXCR1 and shows IL-8-like chemokine activity on monocytes through Rho/ROCK activation. Blood 2012, 119, 2274-2283. [CrossRef]

136. Caccuri, F.; Giagulli, C.; Bugatti, A.; Benetti, A.; Alessandri, G.; Ribatti, D.; Marsico, S.; Apostoli, P.; Slevin, M.A.; Rusnati, M.; et al. HIV-1 matrix protein 17 promotes angiogenesis via chemokine receptors CXCR1 and CXCR2. Proc. Natl. Acad. Sci. USA 2012, 109, 14580-14585. [CrossRef] [PubMed]

137. Caccuri, F.; Rueckert, C.; Giagulli, C.; Schulze, K.; Basta, D.; Zicari, S.; Marsico, S.; Cervi, E.; Fiorentini, S.; Slevin, M.; et al. HIV-1 matrix protein p17 promotes lymphangiogenesis and activates the endothelin-1/endothelin B receptor axis. Arter. Thromb. Vasc. Biol. 2014, 34, 846-856. [CrossRef] [PubMed]

138. Fiorentini, S.; Giagulli, C.; Caccuri, F.; Magiera, A.K.; Caruso, A. HIV-1 matrix protein p17: A candidate antigen for therapeutic vaccines against AIDS. Pharmacol. Ther. 2010, 128, 433-444. [CrossRef] [PubMed]

139. Caccuri, F.; Giordano, F.; Barone, I.; Mazzuca, P.; Giagulli, C.; Ando, S.; Caruso, A.; Marsico, S. HIV-1 matrix protein p17 and its variants promote human triple negative breast cancer cell aggressiveness. Infect. Agents Cancer 2017, 12, 49. [CrossRef] [PubMed]

140. Carroll, V.A.; Lafferty, M.K.; Marchionni, L.; Bryant, J.L.; Gallo, R.C.; Garzino-Demo, A. Expression of HIV-1 matrix protein p17 and association with B-cell lymphoma in HIV-1 transgenic mice. Proc. Natl. Acad. Sci. USA 2016, 113, 13168-13173. [CrossRef] [PubMed]

141. Ivanov, A.V.; Valuev-Elliston, V.T.; Ivanova, O.N.; Kochetkov, S.N.; Starodubova, E.S.; Bartosch, B.; Isaguliants, M.G. Oxidative stress during HIV infection: Mechanisms and consequences. Oxidative Med. Cell. Longev. 2016, 2016. [CrossRef]

142. El-Amine, R.; Germini, D.; Zakharova, V.V.; Tsfasman, T.; Sheval, E.V.; Louzada, R.A.N.; Dupuy, C.; Bilhou-Nabera, C.; Hamade, A.; Najjar, F.; et al. HIV-1 Tat protein induces DNA damage in human peripheral blood B-lymphocytes via mitochondrial ROS production. Redox Biol. 2018, 15, 97-108. [CrossRef]

143. Estrada, V.; Monge, S.; Gomez-Garre, M.D.; Sobrino, P.; Masia, M.; Berenguer, J.; Portilla, J.; Vilades, C.; Martinez, E.; Blanco, J.R.; et al. Relationship between plasma bilirubin level and oxidative stress markers in HIV-infected patients on atazanavirvs. efavirenz-based antiretroviral therapy. HIV Med. 2016, 17, 653-661. [CrossRef]

144. Kolgiri, V.; Nagar, V.; Patil, V. Association of serum total bilirubin and plasma 8-OHdG in HIV/AIDS patients. Interv. Med. Appl. Sci. 2018, 10, 76-82. [CrossRef] [PubMed]

145. Porter, K.M.; Sutliff, R.L. HIV-1, reactive oxygen species, and vascular complications. Free Radic. Biol. Med. 2012, 53, 143-159. [CrossRef] [PubMed]

146. Price, T.O.; Ercal, N.; Nakaoke, R.; Banks, W.A. HIV-1 viral proteins gp120 and Tat induce oxidative stress in brain endothelial cells. Brain Res. 2005, 1045, 57-63. [CrossRef] [PubMed]

147. Gu, Y.; Wu, R.F.; Xu, Y.C.; Flores, S.C.; Terada, L.S. HIV Tat activates c-Jun amino-terminal kinase through an oxidant-dependent mechanism. Virology 2001, 286, 62-71. [CrossRef]

148. Capone, C.; Cervelli, M.; Angelucci, E.; Colasanti, M.; Macone, A.; Mariottini, P.; Persichini, T. A role for spermine oxidase as a mediator of reactive oxygen species production in HIV-Tat-induced neuronal toxicity. Free Radic. Biol. Med. 2013, 63, 99-107. [CrossRef]

149. Perry, S.W.; Norman, J.P.; Litzburg, A.; Zhang, D.; Dewhurst, S.; Gelbard, H.A. HIV-1 transactivator of transcription protein induces mitochondrial hyperpolarization and synaptic stress leading to apoptosis. J. Immunol. 2005, 174, 4333-4344. [CrossRef]

150. Pocernich, C.B.; Sultana, R.; Mohmmad-Abdul, H.; Nath, A.; Butterfield, D.A. HIV-dementia, Tat-induced oxidative stress, and antioxidant therapeutic considerations. Brain Res. Rev. 2005, 50, 14-26. [CrossRef] 
151. Wu, R.F.; Ma, Z.; Liu, Z.; Terada, L.S. Nox4-derived $\mathrm{H}_{2} \mathrm{O}_{2}$ mediates endoplasmic reticulum signaling through local Ras activation. Mol. Cell. Biol. 2010, 30, 3553-3568. [CrossRef]

152. Helmcke, I.; Heumuller, S.; Tikkanen, R.; Schroder, K.; Brandes, R.P. Identification of structural elements in Nox1 and Nox4 controlling localization and activity. Antioxidants Redox Signal. 2009, 11, 1279-1287. [CrossRef]

153. Pietraforte, D.; Tritarelli, E.; Testa, U.; Minetti, M. gp120 HIV envelope glycoprotein increases the production of nitric oxide in human monocyte-derived macrophages. J. Leukoc. Biol. 1994, 55, 175-182. [CrossRef]

154. Shah, A.; Kumar, S.; Simon, S.D.; Singh, D.P.; Kumar, A. HIV gp120- and methamphetamine-mediated oxidative stress induces astrocyte apoptosis via cytochrome P450 2E1. Cell Death Dis. 2013, 4, e850. [CrossRef] [PubMed]

155. Foga, I.O.; Nath, A.; Hasinoff, B.B.; Geiger, J.D. Antioxidants and dipyridamole inhibit HIV-1 gp120-induced free radical-based oxidative damage to human monocytoid cells. J. Acquir. Immune Defic. Syndr. Hum. Retrovirol. 1997, 16, 223-229. [CrossRef] [PubMed]

156. Ronaldson, P.T.; Bendayan, R. HIV-1 viral envelope glycoprotein gp120 produces oxidative stress and regulates the functional expression of multidrug resistance protein-1 (Mrp1) in glial cells. J. Neurochem. 2008, 106, 1298-1313. [CrossRef]

157. Reddy, P.V.; Gandhi, N.; Samikkannu, T.; Saiyed, Z.; Agudelo, M.; Yndart, A.; Khatavkar, P.; Nair, M.P. HIV-1 gp120 induces antioxidant response element-mediated expression in primary astrocytes: Role in HIV associated neurocognitive disorder. Neurochem. Int. 2012, 61, 807-814. [CrossRef] [PubMed]

158. Olivetta, E.; Pietraforte, D.; Schiavoni, I.; Minetti, M.; Federico, M.; Sanchez, M. HIV-1 Nef regulates the release of superoxide anions from human macrophages. Biochem. J. 2005, 390, 591-602. [CrossRef] [PubMed]

159. Olivetta, E.; Mallozzi, C.; Ruggieri, V.; Pietraforte, D.; Federico, M.; Sanchez, M. HIV-1 Nef induces p47(phox) phosphorylation leading to a rapid superoxide anion release from the U937 human monoblastic cell line. J. Cell. Biochem. 2009, 106, 812-822. [CrossRef] [PubMed]

160. Vilhardt, F.; Plastre, O.; Sawada, M.; Suzuki, K.; Wiznerowicz, M.; Kiyokawa, E.; Trono, D.; Krause, K.-H. The HIV-1 Nef protein and phagocyte NADPH oxidase activation. J. Biol. Chem. 2002, 277, 42136-42143. [CrossRef]

161. Masanetz, S.; Lehmann, M.H. HIV-1 Nef increases astrocyte sensitivity towards exogenous hydrogen peroxide. Virol. J. 2011, 8, 35. [CrossRef]

162. Chelvanambi, S.; Gupta, S.K.; Chen, X.; Ellis, B.W.; Maier, B.F.; Colbert, T.M.; Kuriakose, J.; Zorlutuna, P.; Jolicoeur, P.; Obukhov, A.G.; et al. HIV-Nef Protein Transfer to Endothelial Cells Requires Rac1 Activation and Leads to Endothelial Dysfunction Implications for Statin Treatment in HIV Patients. Circ. Res. 2019, 125, 805-820. [CrossRef]

163. Isaguliants, M.; Smirnova, O.; Ivanov, A.V.; Kilpelainen, A.; Kuzmenko, Y.; Petkov, S.; Latanova, A.; Krotova, O.; Engström, G.; Karpov, V. Oxidative stress induced by HIV-1 reverse transcriptase modulates the enzyme's performance in gene immunization. Hum. Vacc. Immunother. 2013, 9, 2111-2119. [CrossRef]

164. Massiah, M.A.; Starich, M.R.; Paschall, C.; Summers, M.F.; Christensen, A.M.; Sundquist, W.I. Three-dimensional structure of the human immunodeficiency virus type 1 matrix protein. J. Mol. Biol. 1994, 244, 198-223. [CrossRef] [PubMed]

165. Doherty, R.S.; De Oliveira, T.; Seebregts, C.; Danaviah, S.; Gordon, M.; Cassol, S. BioAfrica's HIV-1 proteomics resource: Combining protein data with bioinformatics tools. Retrovirology 2005, 2, 18. [CrossRef] [PubMed]

166. Zeinolabediny, Y.; Caccuri, F.; Colombo, L.; Morelli, F.; Romeo, M.; Rossi, A.; Schiarea, S.; Ciaramelli, C.; Airoldi, C.; Weston, R.; et al. HIV-1 matrix protein p17 misfolding forms toxic amyloidogenic assemblies that induce neurocognitive disorders. Sci. Rep. 2017, 7, 10313. [CrossRef]

167. Cheignon, C.; Tomas, M.; Bonnefont-Rousselot, D.; Faller, P.; Hureau, C.; Collin, F. Oxidative stress and the amyloid beta peptide in Alzheimer's disease. Redox Biol. 2018, 14, 450-464. [CrossRef] [PubMed]

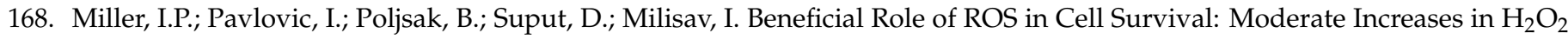
Production Induced by Hepatocyte Isolation Mediate Stress Adaptation and Enhanced Survival. Antioxidants 2019, 8, 434. [CrossRef]

169. Ajasin, D.; Eugenin, E.A. HIV-1 Tat: Role in Bystander Toxicity. Front. Cell. Infect. Microbiol. 2020, 10, 61. [CrossRef]

170. Debaisieux, S.; Rayne, F.; Yezid, H.; Beaumelle, B. The ins and outs of HIV-1 Tat. Traffic 2012, 13, 355-363. [CrossRef]

171. Clark, E.; Nava, B.; Caputi, M. Tat is a multifunctional viral protein that modulates cellular gene expression and functions. Oncotarget 2017, 8, 27569-27581. [CrossRef]

172. Marino, J.; Wigdahl, B.; Nonnemacher, M.R. Extracellular HIV-1 Tat Mediates Increased Glutamate in the CNS Leading to Onset of Senescence and Progression of HAND. Front. Aging Neurosci. 2020, 12, 168. [CrossRef]

173. Montano, M.A.; Novitsky, V.A.; Blackard, J.T.; Cho, N.L.; Katzenstein, D.A.; Essex, M. Divergent transcriptional regulation among expanding human immunodeficiency virus type 1 subtypes. J. Virol. 1997, 71, 8657-8665. [CrossRef]

174. Karn, J.; Stoltzfus, C.M. Transcriptional and posttranscriptional regulation of HIV-1 gene expression. Cold Spring Harb. Perspect. Med. 2012, 2, a006916. [CrossRef] [PubMed]

175. Albini, A.; Ferrini, S.; Benelli, R.; Sforzini, S.; Giunciuglio, D.; Aluigi, M.G.; Proudfoot, A.E.; Alouani, S.; Wells, T.N.; Mariani, G.; et al. HIV-1 Tat protein mimicry of chemokines. Proc. Natl. Acad. Sci. USA 1998, 95, 13153-13158. [CrossRef] [PubMed]

176. Eugenin, E.A.; Dyer, G.; Calderon, T.M.; Berman, J.W. HIV-1 tat protein induces a migratory phenotype in human fetal microglia by a CCL2 (MCP-1)-dependent mechanism: Possible role in NeuroAIDS. Glia 2005, 49, 501-510. [CrossRef] [PubMed] 
177. El-Hage, N.; Wu, G.; Wang, J.; Ambati, J.; Knapp, P.E.; Reed, J.L.; Bruce-Keller, A.J.; Hauser, K.F. HIV-1 Tat and opiate-induced changes in astrocytes promote chemotaxis of microglia through the expression of MCP-1 and alternative chemokines. Glia 2006, 53, 132-146. [CrossRef]

178. Lawrence, D.M.; Seth, P.; Durham, L.; Diaz, F.; Boursiquot, R.; Ransohoff, R.M.; Major, E.O. Astrocyte differentiation selectively upregulates CCL2/monocyte chemoattractant protein-1 in cultured human brain-derived progenitor cells. Glia 2006, 53, 81-91. [CrossRef]

179. Youn, G.S.; Ju, S.M.; Choi, S.Y.; Park, J. HDAC6 mediates HIV-1 tat-induced proinflammatory responses by regulating MAPK-NFkappaB/AP-1 pathways in astrocytes. Glia 2015, 63, 1953-1965. [CrossRef]

180. Clouse, K.A.; Cosentino, L.M.; Weih, K.A.; Pyle, S.W.; Robbins, P.B.; Hochstein, H.D.; Natarajan, V.; Farrar, W.L. The HIV-1 gp120 envelope protein has the intrinsic capacity to stimulate monokine secretion. J. Immunol. 1991, 147, $2892-2901$.

181. Kalyanaraman, V.S.; Rodriguez, V.; Veronese, F.; Rahman, R.; Lusso, P.; DeVico, A.L.; Copeland, T.; Oroszlan, S.; Gallo, R.C.; Sarngadharan, M.G. Characterization of the secreted, native gp120 and gp160 of the human immunodeficiency virus type 1. AIDS Res. Hum. Retroviruses 1990, 6, 371-380. [CrossRef]

182. Oh, S.-K.; Cruikshank, W.W.; Raina, J.; Blanchard, G.C.; Adler, W.H.; Walker, J.; Kornfeld, H. Identification of HIV-1 envelope glycoprotein in the serum of AIDS and ARC patients. J. Acquir. Immune Defic. Syndr. 1992, 5, 251-256. [CrossRef]

183. Jones, M.V.; Bell, J.E.; Nath, A. Immunolocalization of HIV envelope gp120 in HIV encephalitis with dementia. AIDS 2000, 14, 2709-2713. [CrossRef]

184. Berth, S.; Caicedo, H.H.; Sarma, T.; Morfini, G.; Brady, S.T. Internalization and axonal transport of the HIV glycoprotein gp120. ASN Neuro 2015, 7. [CrossRef] [PubMed]

185. Marone, G.; Rossi, F.W.; Pecoraro, A.; Pucino, V.; Criscuolo, G.; Paulis, A.; Spadaro, G.; Marone, G.; Varricchi, G. HIV gp120 Induces the Release of Proinflammatory, Angiogenic, and Lymphangiogenic Factors from Human Lung Mast Cells. Vaccines 2020, 8, 208. [CrossRef] [PubMed]

186. Caby, M.-P.; Lankar, D.; Vincendeau-Scherrer, C.; Raposo, G.; Bonnerot, C. Exosomal-like vesicles are present in human blood plasma. Int. Immunol. 2005, 17, 879-887. [CrossRef] [PubMed]

187. Ferdin, J.; Goricar, K.; Dolzan, V.; Plemenitas, A.; Martin, J.N.; Peterlin, B.M.; Deeks, S.G.; Lenassi, M. Viral protein Nef is detected in plasma of half of HIV-infected adults with undetectable plasma HIV RNA. PLoS ONE 2018, 13, e0191613. [CrossRef] [PubMed]

188. Lenassi, M.; Cagney, G.; Liao, M.; Vaupotič, T.; Bartholomeeusen, K.; Cheng, Y.; Krogan, N.J.; Plemenitaš, A.; Peterlin, B.M. HIV Nef is secreted in exosomes and triggers apoptosis in bystander CD4 + T cells. Traffic 2010, 11, 110-122. [CrossRef] [PubMed]

189. Chettimada, S.; Lorenz, D.R.; Misra, V.; Dillon, S.T.; Reeves, R.K.; Manickam, C.; Morgello, S.; Kirk, G.D.; Mehta, S.H.; Gabuzda, D. Exosome markers associated with immune activation and oxidative stress in HIV patients on antiretroviral therapy. Sci. Rep. 2018, 8, 7227. [CrossRef] [PubMed]

190. James, C.O.; Huang, M.-B.; Khan, M.; Garcia-Barrio, M.; Powell, M.D.; Bond, V.C. Extracellular Nef protein targets CD4 + T cells for apoptosis by interacting with CXCR4 surface receptors. J. Virol. 2004, 78, 3099-3109. [CrossRef]

191. Qiao, X.; He, B.; Chiu, A.; Knowles, D.M.; Chadburn, A.; Cerutti, A. Human immunodeficiency virus 1 Nef suppresses CD40-dependent immunoglobulin class switching in bystander B cells. Nat. Immunol. 2006, 7, 302-310. [CrossRef]

192. Saribas, A.S.; Cicalese, S.; Ahooyi, T.M.; Khalili, K.; Amini, S.; Sariyer, I.K. HIV-1 Nef is released in extracellular vesicles derived from astrocytes: Evidence for Nef-mediated neurotoxicity. Cell Death Dis. 2018, 8, e2542. [CrossRef]

193. Anyanwu, S.I.; Doherty, A.; Powell, M.D.; Obialo, C.; Huang, M.B.; Quarshie, A.; Mitchell, C.; Bashir, K.; Newman, G.W. Detection of HIV-1 and Human Proteins in Urinary Extracellular Vesicles from HIV+ Patients. Adv. Virol. 2018, 2018, 1-16. [CrossRef]

194. Caccuri, F.; Iaria, M.L.; Campilongo, F.; Varney, K.; Rossi, A.; Mitola, S.; Schiarea, S.; Bugatti, A.; Mazzuca, P.; Giagulli, C.; et al. Cellular aspartyl proteases promote the unconventional secretion of biologically active HIV-1 matrix protein p17. Sci. Rep. 2016, 6, 38027. [CrossRef] [PubMed]

195. Dolcetti, R.; Gloghini, A.; Caruso, A.; Carbone, A. A lymphomagenic role for HIV beyond immune suppression? Blood 2016, 127, 1403-1409. [CrossRef] [PubMed]

196. Popovic, M.; Tenner-Racz, K.; Pelser, C.; Stellbrink, H.J.; van Lunzen, J.; Lewis, G.; Kalyanaraman, V.S.; Gallo, R.C.; Racz, P. Persistence of HIV-1 structural proteins and glycoproteins in lymph nodes of patients under highly active antiretroviral therapy. Proc. Natl. Acad. Sci. USA 2005, 102, 14807-14812. [CrossRef] [PubMed] 